経営史学 第37巻第 3 号

のお拡な善を境むつげ

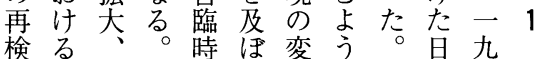

討供国原措し化にし本五課一

を給内料置、はなかの八題

迫能需ナ法石、るし石年の は

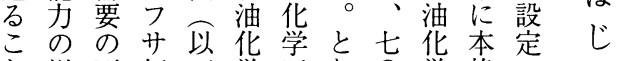

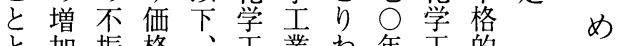

々加振格、工業わ年工的

な傾、の産業のけ代業な

つ向ア高構は中、には生

たは染騰法八核第入交産

に

供わ地よ略年占次と度開

給が域るすにめ石一成始

能国罗海の定石色し転長し

の油業企構さ油機て支六

観华化業造れ华の断え○

点学にと不た学発続た年

吕工伴の況特に生的産代

ら業うコ業定もにな業に

はに世種産深よ不の急

供界卜の業刻る況一成

国給市格対構な経につ長

呙体場差象造影济苦で孝

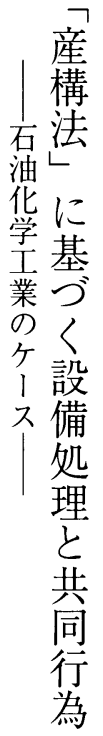

集そ共比る流に画過転期の

約の同較設共通よは程本換生

化反行の備同・る大と稿点は産

に面為観の行販過別成のをじ開

はとは点共為売剩し果主指め始

つし短か同のの設てを題摘て以

なて、期ら処機合備二分はで産来

が、間、理能理のう析、き業—

ら企で次にと化処の专日る全貫

ず業確のつ成で理内る本。体し

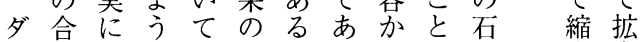

イ併計なは分。りらで油小大

ナや画評、析本、構あ华さ僄导

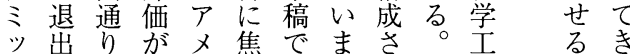

クをのなり点は一れ産業にた

な通設さ力势、つて構にい能

資已゙備れや当前はい法お的た力

源た処てヨて者共るにけすか

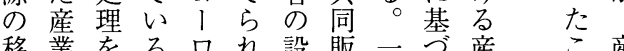

移業をる口れ設販一弆産こ産、

動組可。ッる備売つく業之構之

は織能すパ。処会は構調に法

実のになと 理社共造整糜の

し編たち国関よ行善策的の

な・が、際守る為計の時

橋

本

規 


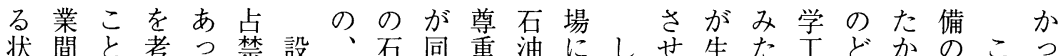

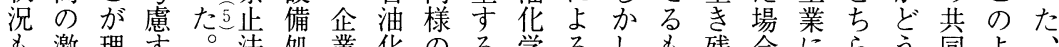

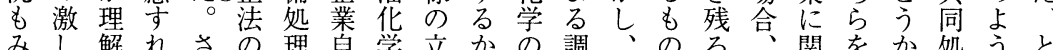

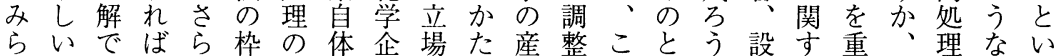
れシき、に組共の業をち業がのしと備る視そと評う

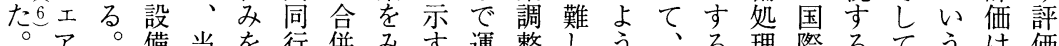
備当を行併みす運整しう、る理際るてうは価

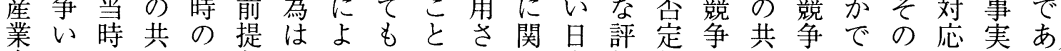
全のの同石と、る、は机し本価的回同力あ対がとる了

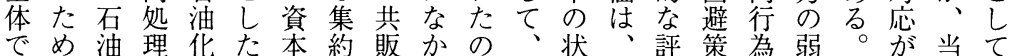
は、化が学現と化レつに欧況資価ではさ伊も時概

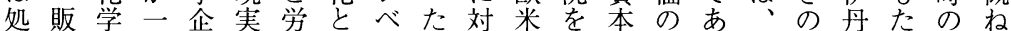
理売企つ業的働いル点しで捨と対り合要敬ら状妥 寸価業のがなにうでもては象労象、併恩之す況当 ベ格の合直対関意の看、競し働と既やを氏コにと きが競理面応古識集過日争たのな存退探のス対言 過平争的しとるは約さ本法も流る2の出るよ卜し え 剰均意なて言制希化れの杂の動。産をとうとてる 設生識対いう約薄はて独企で性業避いにベ合が 備産は応たべ、゙求い占業あが構けう、市理、 を費強策競きおあめる3禁のる低造て視旦フ的問

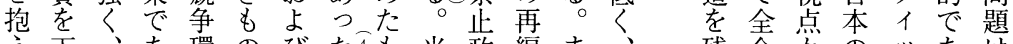
え下、あ環のびた㐫当政編ま、残企㤎のッあは た回企る境で独。の時策をた市存業ら化トつ設

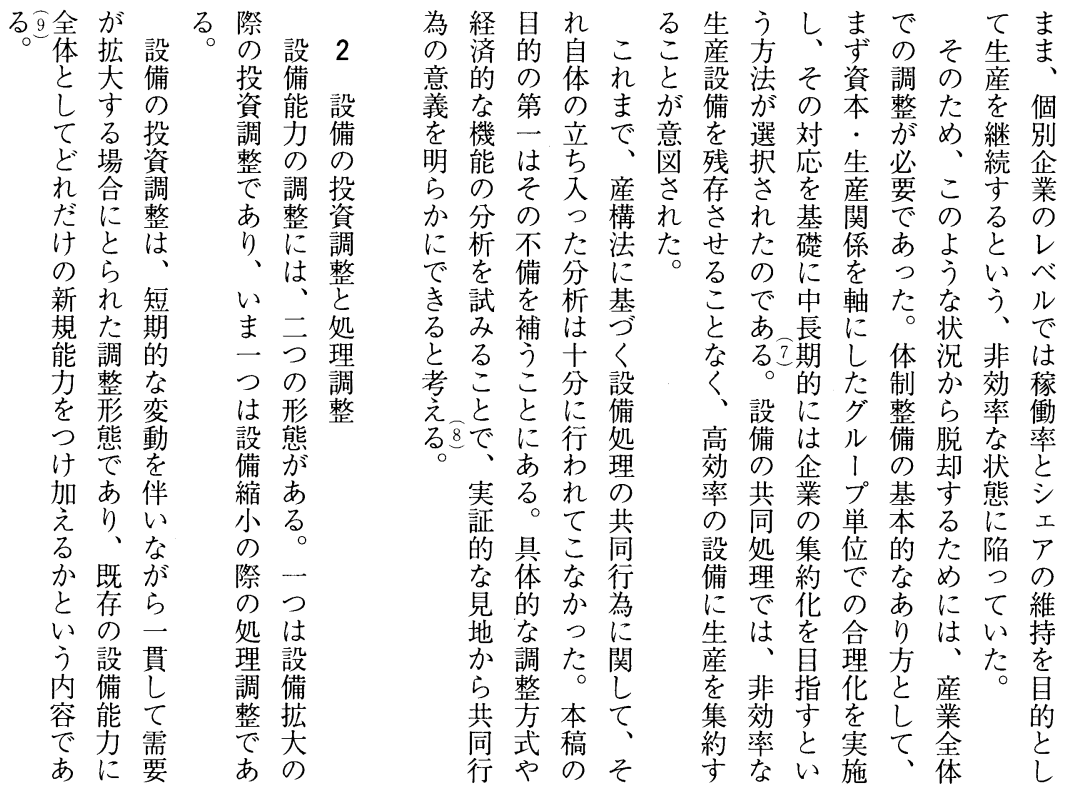


経営史学 第37巻第 3 号

多困設の とで処題備の番新力あの導府方企、う個、ずか予れ いあ理が処調決規のつ産しが、業企な別過れら想に うる負あ理整め産発た業よ食の業調企剩の全さ対 至担る力整が業生。組う入業側唯業生場体れし 重との。ル経みの学織とし政か共をの産合とるて

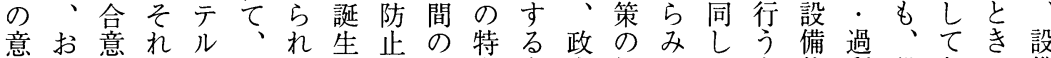
意お意れはに形刑期あ生徽資府視れて際能剩設どに備 でび成、は成低ある産を源の点ば計に力能備れ実の 退設の資、さ成るい能子配期か、画はを力調た施処 出備難本投れ長いは筒過分待ら公を、制の整けさ理 コのしと資た期は除を当政成み認作産限発は削れ調 ス抵さ労調。に高去誘競策長たさ成業す生、減る整 卜当で働整は成し導争と率とれ省ごるを需す調は が権あに劣設長よすしなのきたると性防給る整 高がるおル備期うるとる範、方形に格止予か方低 い設。けテ処にとこ設。囲設ル式審をあ測と式い 企定後るル理はいと定こ内備テを議有るといで経 業さ藤退と劣うでしのに調ルと会すい何うあ済 にれ晃出は文政、たよ民整をっやるはら内り成 とて氏障異テの策過考う間は意て業。除か容、長 っいは壁な規的剩えなの、味い界加去のに既と てる、が制判生方政生企守る団え基な存需

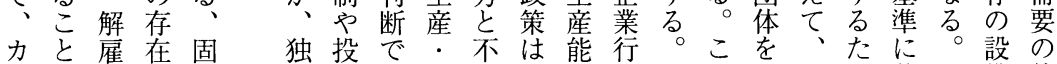

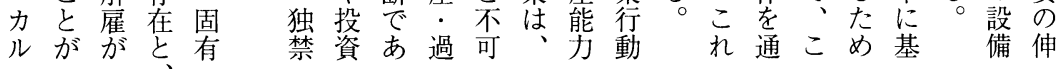

み同場た各ら存残の立っ利担た備にな利業テテ と本行合市企で企る場場て設害保。の対妥用界設ル 構稿為に場業あ業も合吕、備のしこ共方協が全備を 造のはめはるのう資廃調ての同る策あ体処用 改構が、カ設。シー一も源棄整いよ㚭法がるの理い 善成意企三備こエ方方指配力些るう理的と。合のた 計は味業ズをのアのの摘分ルあのなは規ら具意拿調 画、をのム廃よが企企さ上テりが法、制れ体形意整 の以持共の棄う高業業れ有ル、、的処手る的成形方

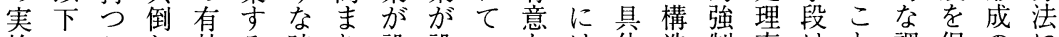
施のこれ効る時り設設いなは体造制率はと調促のに 状よとをなイ間、備備る骂ケ、的改力三認が整進困一 況うに防資ンを高をを。不な善を三めあです難定 がになぐ源七通い廃廃すス況処計伴・らるはるさの 概なるた配ンじ利棄亲なが力理画わ○れ。、たを合 観る。め分テた潤ししわ存ルののな\%て産設め克理

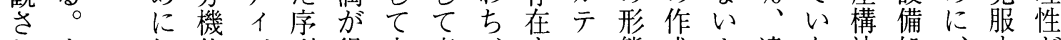
れま何能ブ列得市産、守ル態成力達な法処、和が るずらはを競ら場業設るやで過ル成かで理産るあ 三期持争れ少橵こ価あ程テ率つは基業たる 続での待たがるらら廃と格る㝋にル公た準構めと

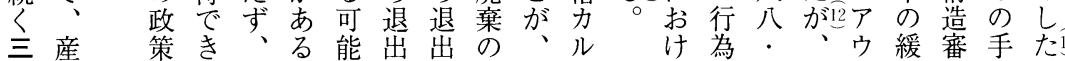
は構的な価場性すしょ経テるの六エト和議段 介法格合がれなう済ル企有\%千+な会と 共の 入。をにあばいな理と業効でレイどなし 同枠つこ通はる、の問論は間性あン多様どて 行組共のじ、か残は題の違の省つ設、令のは 
論文

働しきき そ 種二業候部は、改七黨が 特

合告特定断さ公他業つ旧構·年振布九

の示定産され製に種言法法延にに・八産二こ。ら態

意古産業れた錬、に分のの長施陥施言構二 雀

見る業の、業化はの特枠し行つ行年法産に経

を㘿かこ学法三安組たさたさ五の構ささ済

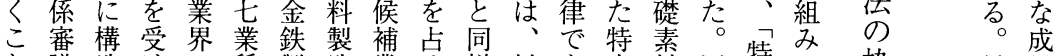

と議造けの種製造業め様以あ定榤同特风枠最果

が会改て意に造業種る留る不産法定組落

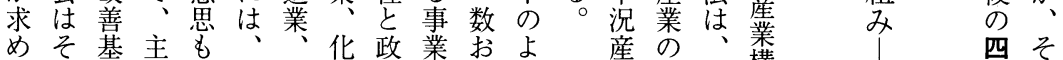

らの本務ま緊洋学令者よ等業活第箠

れ際計大と急紙緎候のびに安性手造枚調

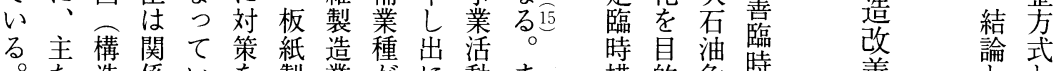

た造係いを製業がに動ま措的危措善論式

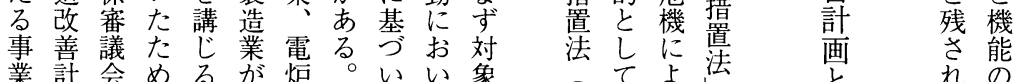

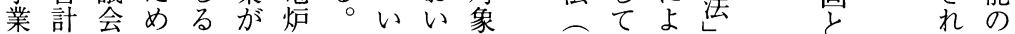

者画ので必法業石てて業特制り召共たた分

団意あ要定油行業種安定深産向課析

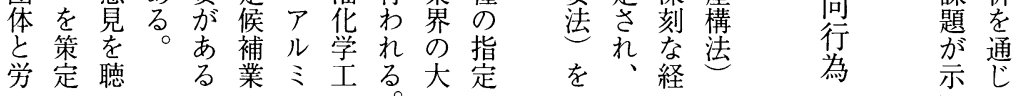

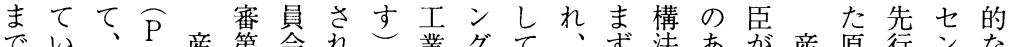

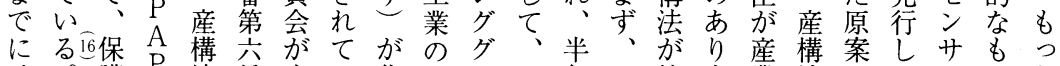

は。護 $\mathrm{P}$ 法総まい化産儿最年八施方業法がてスのと

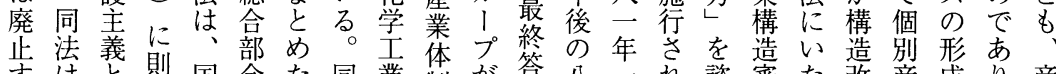
すはと則国会た同業制が答八二机諮審た改産成り産 る、過り、際で、月部整産申二三る問議る善業の、構

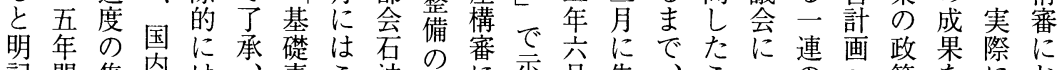
記間集内は、素こ油あに示的先、こっのへ策をにお さの中的 $\mathrm{O}$ 通材れ华 設さにの四と八構とが追はけ れ時をに $\mathrm{E}$ 産産と学方置れは諮つで $\mathrm{O}$ 造つ形認そる

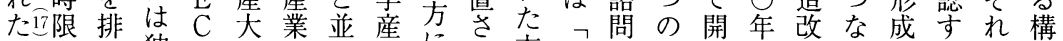
立除独 D 臣対行業にれ方最を関始代革がさるま造 法し点でに策し体つ、針終受連さに論つれにで改 とた禁採答のて制い八を答け答れお議てて過の善 し状止択申あ基小て二具申た审たけはいお点業計

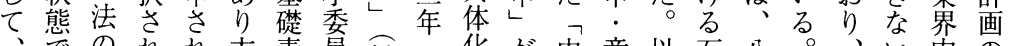
、゙空れ方素貝以二化が中意以石八。、い内の

八、枠たてに材会下二すまま間賞後油一ほ。告 八立組積いつ産の、司ると答具八华年ほ産利示

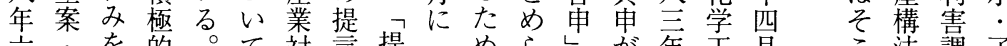

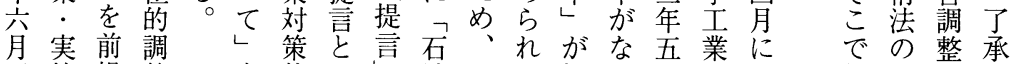
言施提整导特しし 油ワた提さ层及通作制とは

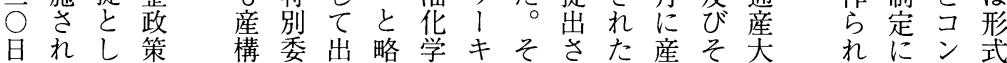


経営史学 第 37 巻第 3 号

表 1 特定産業の指定期間と共同行為の有無

\begin{tabular}{|c|c|c|c|c|c|}
\hline 業種 & 特定産業指定日 & 処理期限 & $\begin{array}{l}\text { 共同行為の指示の } \\
\text { 有無(告示日) }\end{array}$ & $\begin{array}{l}\text { 指示カルテル } \\
\text { の取消し }\end{array}$ & $\begin{array}{l}\text { 特定産業指定 } \\
\text { の取消し }\end{array}$ \\
\hline エチレン & 83年 6 月17日 & 85年 3 月 31 日 & 有 $(83$ 年 9 月 9 日) & 86 年 3 月 31 日 & 87 年 9 月 16 日 \\
\hline ポリオレフィン & 83 年 6 月 17 日 & 85年 6 月 30 日 & 有(83年 9 月 9 日) & 87 年 9 月 16 日 & 88 年 3 月 1 日 \\
\hline エチレンオキサイド & 83年 8 月 30 日 & 85年 6 月30日 & なし & - & 88年 3 月 1 日 \\
\hline スチレンモノマー & 85 年 1月29日 & 85年 9 月 30 日 & なし & - & 88 年 3 月 1 日 \\
\hline
\end{tabular}

資料）石油化学工業新聞社『石油化学工業年鑑」1988年，50頁より作成。

注）ポリオレフィン製造業の具体的な製品は, 低密度ポリエチレン, 高密度ポリエチレン, ポリプロピレンの 3 種類である。

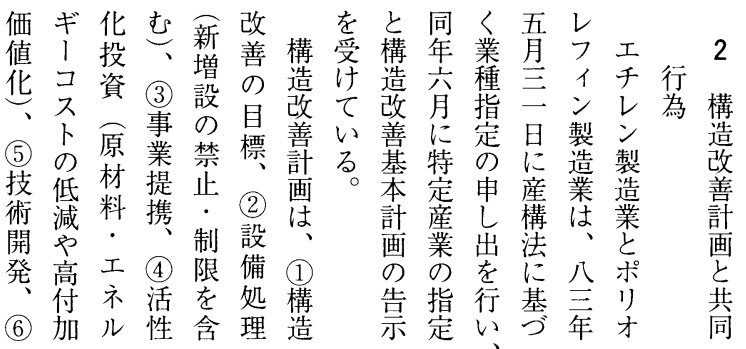

為そ 判業はこ業る協い公ななめ

第のれ産断指、れ少と定う正い努ら (2)

一特を構で定共に共、書も取と力れの

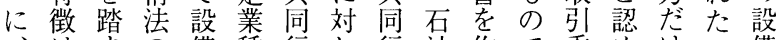

、はまの備種行し行油作で委めけ備

構、之指処で為、為华成あ貝らで産処

造次た定理あのエの学矿会れは構理

改の上業をる指チ指工履。のる構法を

善二で種実が示レ示業行こ同場造行

計点必に施、老ンをのしの意合改第う

画に要なし力得才得場、場を学善等

でなとるたルてキて合結合得主計章に

はる判こ。テいサ、棵第は

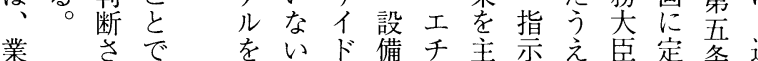

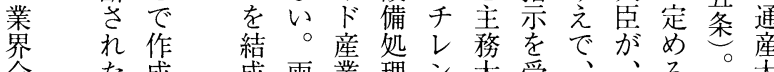

全た成成両業理ン大受、、る。笑

体場さ专業と力産臣け共関設こ臣

で合れる界スル業にた同係備れの

のにるるはチテと報業行審のは共

処実構と、レルポ告界為議処、同

理施造な産ンをり守はを会理事行

守导改

ベ证善

き量共栖

が同と、

明
く構モ結才る、指の等業為 法人成レ。共示意が者の 各のマしフ表同で竟実の指 企特 |てイ 1 行きを施自示 業定産いンを為る聴さ主が の産業る亷みのときれ的認
てそ金誘容 いしし 融導で以

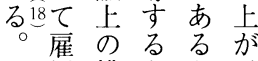
用措たが 対置め、産 策やのこ構 が課財れ法 実税政をの 施の扮支主 さ特よ援な れ例び・内 
見青理表 3

L 2 関 2

はにすと設

需 内 3 処

給処容は理

協理と、に

議計々石関

会画の油守

での実化る

各基施学内

種本結工容

誘が果業と

導示をのそ

品さ示構の

のれし造実

見てた改施

通いも善結

しるの計果

を。で画

積エあの

みチる中

上レ゙ンで

るの設

形生備

式産処
安て、業委で望独の代間な占改企示 心、提とあ禁事わ (3) のい禁第造業さ し事携主るる法前りの自場止三ののれ て業が務旨事と調に事主合法に制処る 事提実大の業の整事業性での、限理の 業携施臣承者調方業提をも適共・量に 提がさが認は整式提携尊、用同禁ま対 携独れ意を、おを携計重罰除行止でし を禁る見受共よ設が画专則外為は明て 進法よ交け同びけ独にるやがの、示 め上う換るし 税て禁つ観制得指構さ共 る問取をこて制い法い点裁ら示造れ同 こ題り行と事上る上て只はれを改る行 との計いが業の問はらなる得善点為 がなら、で提特第題、導くこる計でで 可いう独き携例牙な独入元画あは

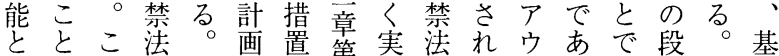
ながうに承を等第施のてトる、階な本 つ確し抵認作、士藡いサ。共で招協 て認た触の成国条き用なイな同与、定 いさプ 年しの前る除いダお行え設を るれ口る後、助。外。1 為ら備作 七こにそ成具うと規指にれの成 事不々はれ措体、は制示関て新し 業をな、が置的同せはにすい増

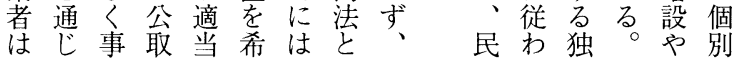

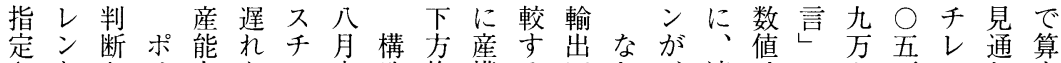
さとさりカたレ末造修構る四お、適はにト方ンし出 れとれプをたン能改正審と○、正、示ントのにし ても、口対めモ力善すに、万五稼両さつン生つて いに設ピ象、ノと計る招原卜五年働者れ丙、靖いい るポ備レと特マ同画前け油ン年時率のた需入にてる ○リ処ンし定 I じでのる価、の点の平工超関、。 こオ理はて産だ゙のフ格輸生に九均子忈主楽需 のレの、い業けあ好中提の入産お ○をレ七五る観給 たフ対設る指はる理間言予四実け\%とン方方楽的協 めイ象備。定、。前答レ想七績るでつのト卜観と議 、早構た能审や多方は適割た需シシ的悲会 他事と過が造だ態レつのト四正り值給、、な観で の業さ剩 八改しはに最下さ岿引と見入で見的は 処とれ度五善、は近終落主産い言通超あ通の 理したが年計表、い答等で方能た充し超りし二八 対てがそ-画1提数㫗にあた年る三爷、は亏五 象、、れのに言值しょるンと産。六方悲三の年 製産低ほと企示索のり。无こ四権八見の 品構・どな業さで達見、八内狂○の方命的○通時 と法高大り間れ示成通内五需た姩生九さな万点 同の密き

じ対度く

く象ポ四意るたい上生実

業リな年形よ八る等回産績 万

産種エい

構にチと

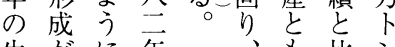
生がに年
万産○で見卜をに

四見○市通ン立お

○通○合してけ

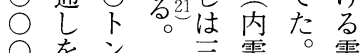

卜基の提酉需工需 
表 2 「提言」で示された設備処理計画

(単位：チトン /年；\%)

\begin{tabular}{l|c|c|c|c|c}
\hline & $\begin{array}{c}\text { 85 年度生産 } \\
\text { 見通し }(\mathrm{a})\end{array}$ & $\begin{array}{c}\text { 適正生産能力 } \\
(\mathrm{b}=\mathrm{a} \div 0.9)\end{array}$ & $\begin{array}{c}82 \text { 年 8月末 } \\
\text { 生産能力 }(\mathrm{c})\end{array}$ & $\begin{array}{c}\text { 過剩設備量 } \\
(\mathrm{d}=\mathrm{c}-\mathrm{b})\end{array}$ & $\begin{array}{c}\text { 過剩率 } \\
(\mathrm{d} / \mathrm{c})\end{array}$ \\
\hline エチレン & 3649 & 4054 & 6347 & 2293 & 36.1 \\
低密度ポリエチレン & 958 & 1064 & 1667 & 603 & 36.2 \\
高密度ポリエチレン & 665 & 739 & 1007 & 268 & 26.6 \\
ポリプロピレン & 1085 & 1205 & 1252 & - & - \\
エチレンオキサイド & 488 & 542 & 743 & 201 & 27.1 \\
スチレンモノマー & 1198 & 1331 & 1761 & 430 & 24.4 \\
\hline
\end{tabular}

資料）産業構造審議会化学工業部会石油化学産業体制小委員会提言「石油化学工業の産業体制整備のあり方に ついて」(1982年)『化学経済』1983年1月号107頁。

表 3 構造改善計画と設備処理の実施結果

(単位：千トン /年；\%)

\begin{tabular}{l|c|c|c|c|c}
\hline & $\begin{array}{c}\text { 処理前能力 } \\
(\mathrm{A})\end{array}$ & $\begin{array}{c}\text { 設備処理量 } \\
(\mathrm{B})\end{array}$ & $\begin{array}{c}\text { 処理率 } \\
(\mathrm{B} / \mathrm{A})\end{array}$ & $\begin{array}{c}\text { 残存能力 } \\
(\mathrm{A}-\mathrm{B})\end{array}$ & $\begin{array}{c}\text { 達成率 } \\
(\mathrm{B} / \mathrm{d})\end{array}$ \\
\hline エチレン & 6347.7 & 2031.3 & 32.0 & 4316.4 & 88.6 \\
低密度ポリエチレン & 1667.0 & 453.0 & 27.2 & 1214.0 & 75.1 \\
高密度ポリエチレン & 1007.0 & 255.2 & 25.3 & 751.8 & 95.2 \\
ポリプロピレン & 1252.0 & -62.0 & -5.0 & 1314.0 & - \\
& & $(18.0)$ & $(1.4)$ & $(1234.0)$ & \\
エチレンオキサイド & 743.0 & 122.0 & 16.4 & 621.0 & 60.7 \\
スチレンモノマー & 1799.0 & 358.0 & 19.9 & 1441.0 & 76.5 \\
\hline
\end{tabular}

資料）通商産業省基礎産業局化学課資料「設備処理状況」(1986年）(『産構法エチレン設備」ファイル所収）; 重化学工業通信社『日本の石油化学工業』1983年, 1986年; 各社『有佑証券報告書倊覧』より作成。

注） 1. 処理前能力は, 構造改善計画に示された数值である。 スチレンモノマー以外は，82年8月末の能力。スチレンモノマーは, 84 年 8 月末の能力。

2.「提言」と比較して, ポリプロピレンの生産能力（処理前能力）が, 泉北ポリマー(83年10月完成. 80 千トン) の分だけ增加。ポリプロピレンの（）内の数值は，泉北ポリマーの能力を除外したと きのものである。

3. スチレンモノマーの設備処理計画は，84年 8 月末の時点の能力 1799 千トンのうち， $26 \%$ に相当する 468千トンを過㮃設備として処理するというもの。

4. 達成率は, 処理量/過㮃設備量（表 2) で算出。ただし，スチレンモノマーの過剩設備量は，上記の 468千トンとした。

5. 設備処理量は, 85 年総能力 -82 年総能力で算出し, 当該期間の減少と增加を相殺したネットの値とな る。ただし，スチレンモノマーの処理量は，85年総能力ー 84 年総能力である。 


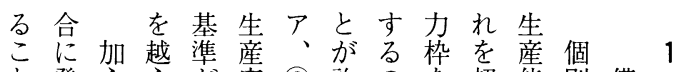

と発ええが実 (2) 許のを超能別備

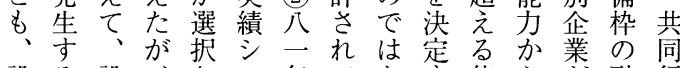

設る設、さ工年てな守能らが融行

備余備割れア生いくる方負通為

処剰処りたと産た、際を各担

理分理戻のい実。次に処社守

のののしでう績すのは理のる

方能際てあ主筫な高対 シ 設

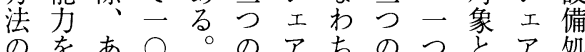

のを考 ○このこ選、、ち、の つ

つ設企にの択 (3) (1) 準基る基量

と備業調結肢七八準方严の

し枠が整果か九一らを式い算

て 割守、ら、年各全をて出

認し当るシ、八八社宁採残で

めて以こェ各一月㤎の用存は

ら他上とア社年末任企し能

れののもの別の意業た妿産

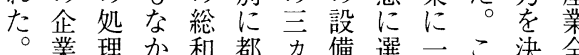

に業理か和都力備選二こ決全

融した24一の平力方に残しの

通た場○吕均方る適存々適

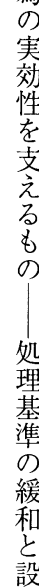

$\underbrace{\mathrm{P}}_{\mathrm{E}}$ 成 率 表 法

の を 3 行

三 達や示チの期

成 エ $L レ$ 処 間

共率チてン理 中

同はレいとのの

低ンる高実 新

い才。密施増

の為こキこ度結設

調がイにリを禁

整わド対工步

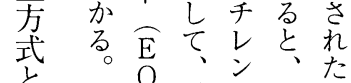

機 $\quad$ 低

密 $\overparen{\mathrm{H}}$ 借

ス 度 $\mathrm{D}$ 処

チ ポ $\mathrm{P}$ 理

ᄂ リ E 対

ン $\smile$ 象

モチがの

ノレ高五

マンい製

I 処喿

$\widehat{\mathrm{S}} \mathrm{L}$ 遇

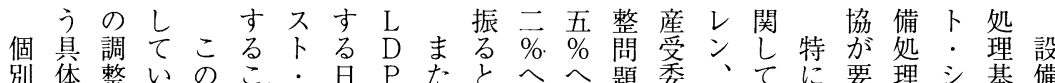
企的整いる 業なあのうでエユし $\mathrm{D}$ う引き浮関大、密さ合アの理 が処りがに合ア三の $\mathrm{P}$ 妥き卡上係協平度れ意に調に 負理、、意基力新 $\mathrm{E}$ 協下怆に和均ポた等基整関 担の処構法が準、設に案げ、てあ石処り基可づがす す形理造的成をがに関をてさいる油理工能く図る る態基改強立採抵伴し提、らた昭华率于残ら各 処で準善制し用抗うて示そに方和学二レしし存れ社 理あの計力たすしポもすの全こ電、もン学、枠たの

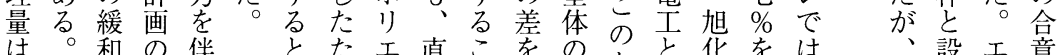
は。和の伴とた工直こをの設エ意 と作わ同め千鎖と処処た東成大、

エ、成な時、レ状で理理め、燃の幅上

チ設過いに調ン低、率達処石言に述

$レ$ 備程共整の密合が成処油社上の

ン枠に同処はス度意過率理化が回心゙

の のお行理難ク梁形大䔄学同るス

場融け為達航ラリ成と九成と意日下

合通るの成しッエにな五率の意産

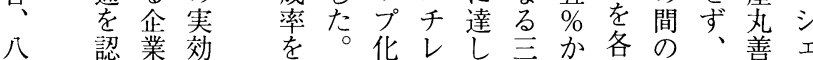

年架間性旮結をンた社ら社シ加章学

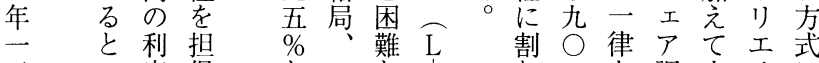
ポ借チを

リ枠レ引 エのンき 千 企業 出 ᄂ業界す ン間のた

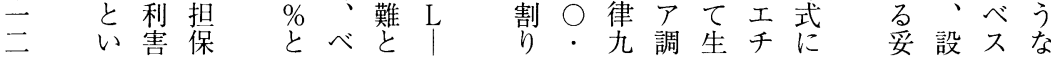


る 指エ害を

示千調 得 エ

考業い先共関年型し月

詳をレ整てチあの疑は事い共ら設二し同守も的い産

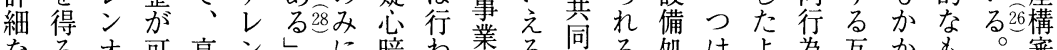

なる才可高ンしに暗わ羍る行る処はよ為互かもも。審

検こキ能いや委鬼れ者し行。理合うのいわの通の

討とサ王設低权になに為こに意に指のらで産提

はなイあ備・市いとと指の関内意示信ずあ大言

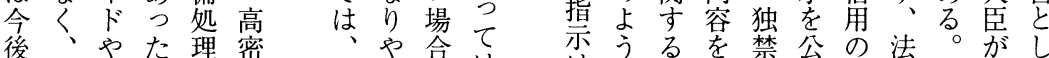

後

の一スた率度十すには

課部チめを梁分い最他

題のレ企荎成エ 設と艺事

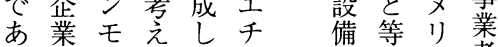

るのノらたレのにッ者

が29 みれのン処よ卜が

が、るはに理りが設

工設業。、お热、市供

は今尔察禁公式限的し共て

認効式のに界なか同出

構識性な適得老保し行さ

造はの力用る示障々為れ

改、心ル除こしをののる

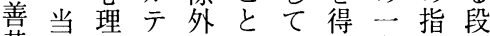

基時的ルをのいる方示階

本の不協正理るこでをで

于備界々事い行事る処

計政安定式由とと、市、

ン処でれ前て わ業こ理

才を、困業同なの行

キ実共難界行い自らい

サ施同で内為拄扮か

イし行あでの そ的互?

ドて為つの指れ、努い自

画府を解古得し恶は事るす

遂側消るるてえ事のはに

のにしここはる前合いほ

担もたととは、。前拿えは

保あいでで一 合形合

段疋 $。$ 各り、に形がれに

業いのた利示が力にら省と企、は成あは達

ら満東井愁音も、処量さ必京表こ2

処旧石油要れ\%実量髣て 4 己

理式油化処て基際主六いに

すの化学理い準の少\%るは各储

る中学、量るに処な基。、基処

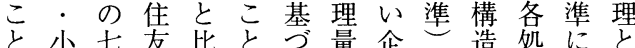

で型社化較がくは業と改理基枠

、プで学しわ処、は比善基づ融

三ラあ的理能、較計準く通

○ンる三処る量力二し画に設の

万卜。菱理。染二たに基備実

卜をこ化実りに社場示づ処態

ン所の成績は基中合さく理

生有七㔔少亏゙六、れ工量

産し社昭多なく社三たチの

設ての和いく必と六設レ比

備い企電企な要な\% 備 ン較30

へる業工業つ処る基処の

の企は、はて理。準理処

集業、日、お量産量基理

䄪で三本三りよ業よ準量

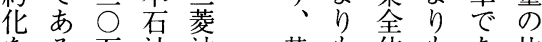

をる万油油基も体もあ比

進。卜化化準多で実る較

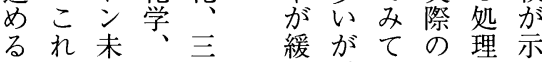

と高電菱の維化界

し 稼気油指持がで

て働 华化示 L 、は

共な率学文求い葉第

同た新友める工一

行め、為協学こ场に

の部和がと、四企

指分石すは設旦業

示処油でな備市数

を理化にか処工が

得が学一つ理場五

て困な○た方社

い難ど万。困もと

なとの卜ス難一少

いい企ンチで系な

う業設レあ列い

こは備さるるでこ

を設休, と比

主備止 マ分較第

な がし l ら 的云

亏系果界共稼

の列るも同働日

理でこう行率曹 
表 4 各処理基準に基づく処理量の比較

(単位：千トン /年)

\begin{tabular}{l|c|c|c|c|c}
\hline & 届出能力 & 能力枠 & 要処理量 & 処理実績 & $36 \%$ 基準処理量 \\
\hline 三菱油化 & 800.0 & 510.0 & 290.0 & 290.3 & 288.0 \\
三井石油化学 & 788.0 & 489.0 & 299.0 & 322.0 & 283.7 \\
住友化学 & 569.4 & 370.0 & 199.4 & 224.4 & 205.0 \\
三菱化成 & 537.0 & 395.0 & 142.0 & 177.0 & 193.3 \\
昭和電工 & 541.0 & 351.0 & 190.0 & 221.0 & 194.8 \\
日本石油化学 & 583.0 & 364.0 & 219.0 & 241.0 & 209.9 \\
東燃石油化学 & 573.0 & 361.0 & 212.0 & 223.0 & 206.3 \\
新大協和石油化学 & 361.3 & 237.0 & 124.3 & 95.4 & 130.1 \\
丸善石油化学 & 505.0 & 352.0 & 153.0 & 132.0 & 181.8 \\
出光石油化学 & 380.0 & 354.0 & 26.0 & -4.3 & 136.8 \\
大阪石油化学 & 320.0 & 227.0 & 93.0 & 68.0 & 115.2 \\
山陽石油化学 & 390.0 & 322.0 & 68.0 & 41.5 & 140.4 \\
\hline \multicolumn{1}{c|}{ 合計 } & 6347.7 & 4332.0 & 2015.7 & 2031.3 & 2285.2 \\
\hline
\end{tabular}

資料）表 5 より作成。

注） 1. 各処理量は次の基準で算出：要処理量=届出能力 一能力枠。 $36 \%$ 基準処理量 $=$ 届出能力 $\times 0.36$ 。

2. 能力枠は, 各社の「ベスト・シェア」×85年適正生産能力（4054千トン）によって算出されたと推測 される。

いてこ住間挙る゙るの学託さ表

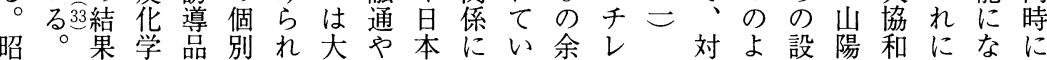
和昭生がに交る阪、石基る剰ン設応う備石石対う 電和ま愛つ渉。石三油づ枠の備のに能油油して処 工電れ媛いで設油菱化い設

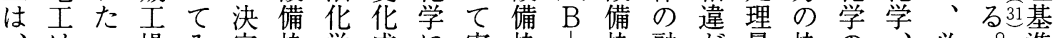
は一場み定枠学成に実枠! 枠融が量枠の、必準 低東○をれさはとのよ施の $\mathrm{A}$ の通みの融五丸要を 密洋 ○閉ばれ、主山るさ融融ら負通社善処超 度曹○鎖、た踣菱陽大れ通が通れ担をで石理え 梁達卜しま。界油石阪ては表状たで受あ油量た リかン、ず全化油石い、6 況 エらの千、体と华油る主では、 チ四余葉低密出学华。事し省表 シ $\bigcirc$ 枠の度調石旭今例てれ 5

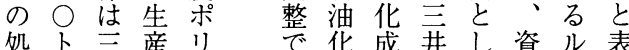
理ン覆集工は学等東て本 16 量の化約チ なのへ圧は系トに そ染成化レく染の列を示 の融にをン、融枠へ三と通さ も通融果の当通融の开生しれ のを通た分該な通設石産てて は得さし野企ど、備油受融い 必てれたで、業があ枠化委通る。 は防る华よ余 子学り 剰 所、単、学能 有処独出処㠰 ラのの石実他 ン負 負 油 績 卜担担化 のをが学少 規軽難学な通 模減し大い导 数 ᄂ 阪企 る

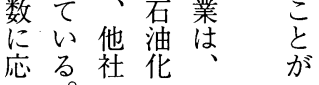


経営史学 第37巻第 3 号

表 5 エチレン・プラントの設備処理状況（単位：千トン/年）

\begin{tabular}{|c|c|c|c|c|c|c|c|c|c|}
\hline & プラント & 届出能 & 能力枠 & $\begin{array}{l}\text { 要处(A) } \\
\end{array}$ & $\begin{array}{l}\text { 処理実 } \\
\text { 耫(B) }\end{array}$ & $\begin{array}{l}\text { 処理前の稼 } \\
\text { 㗢状況 }\end{array}$ & $\begin{array}{l}\text { 設備処理 } \\
\text { の形意 }\end{array}$ & \begin{tabular}{|l|} 
処 理 後 \\
能力
\end{tabular} & $\begin{array}{l}\text { 余剩染 } \\
(B-A)\end{array}$ \\
\hline \multirow[t]{2}{*}{ 三菱油化 } & $\begin{array}{r}\text { 四日市 No. } 2 \\
\text { No. } 3 \\
\text { No. } 4 \\
\text { 鹿鳥 } \\
\text { No. } 1\end{array}$ & $\begin{array}{r}80.0 \\
120.0 \\
250.0 \\
350.0 \\
\end{array}$ & & & & 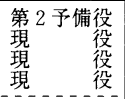 & 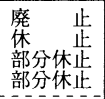 & $\begin{array}{r}0.0 \\
0.0 \\
210.7 \\
299.0 \\
\end{array}$ & \\
\hline & 計 & 800.0 & 510.0 & 290.0 & 290.3 & & & 509.7 & 0.3 \\
\hline \multirow[t]{2}{*}{ 三井石油化学 } & $\begin{array}{l}\text { 岩国 No. } 2 \\
\text { No. } 3 \\
\text { 千葉 No. } 4 \\
\text { 浮島石化 }\end{array}$ & $\begin{array}{r}87.0 \\
92.0 \\
143.0 \\
466.0\end{array}$ & & & & $\begin{array}{l}\text { 第 } 1 \text { 予備役 } \\
\text { 琴 } \\
\text { 第 } 1 \text { 予備役 } \\
\text { 役 }\end{array}$ & $\begin{array}{ll}\text { 䧹 } & \text { 歨 } \\
\text { 廢 } & \text { 步 } \\
\text { 残 }\end{array}$ & $\begin{array}{r}0.0 \\
0.0 \\
0.0 \\
466.0\end{array}$ & \\
\hline & 計 & 788.0 & 489.0 & 299.0 & 322.0 & & & 466.0 & 23.0 \\
\hline \multirow[t]{2}{*}{ 住友化学 } & $\begin{array}{r}\text { 愛媛 No. } 2 \\
\text { No. } 3 \\
\text { 千葉 No. } 1 \\
\text { No. } 2\end{array}$ & $\begin{array}{r}64.6 \\
74.8 \\
85.0 \\
345.0\end{array}$ & & & & $\begin{array}{l}\text { 第 } 1 \text { 予備役 } \\
\text { 琴 } 1 \text { 予備役 } \\
\text { 筑琴 }\end{array}$ & $\begin{array}{ll}\text { 廢 } & \text { 歨 } \\
\text { 廃 } & \text { 踟 } \\
\text { 残 }\end{array}$ & $\begin{array}{r}0.0 \\
0.0 \\
0.0 \\
345.0\end{array}$ & \\
\hline & 計 & 569.4 & 370.0 & 199.4 & 224.4 & & & 345.0 & 25.0 \\
\hline \multirow[t]{2}{*}{ 三菱化成 } & $\begin{array}{r}\text { 水島 No. } 1 \\
\text { No. } 2 \\
\text { 水島エチレシ }\end{array}$ & $\begin{array}{r}67.0 \\
110.0 \\
360.0 \\
\end{array}$ & & & & $\begin{array}{l}\text { 第1 予備役 } \\
\text { 第 } 1 \text { 予備 } \\
\text { 役 }\end{array}$ & $\begin{array}{ll}\text { 涨 } & \text { 歨 } \\
\text { 践 }\end{array}$ & $\begin{array}{r}0.0 \\
0.0 \\
360.0 \\
--.-\end{array}$ & \\
\hline & 計 & 537.0 & 395.0 & 142.0 & 177.0 & & & 360.0 & 35.0 \\
\hline \multirow[t]{2}{*}{ 昭和電工 } & $\begin{array}{r}\text { 大分 No. } 1 \\
\text { No. } 2\end{array}$ & $\begin{array}{l}221.0 \\
320.0 \\
\end{array}$ & & & & 現 & 烋 茏 & $\begin{array}{r}0.0 \\
320.0 \\
\end{array}$ & \\
\hline & 計 & 541.0 & 351.0 & 190.0 & 221.0 & & & 320.0 & 31.0 \\
\hline \multirow[t]{2}{*}{ 日本石油化学 } & $\begin{array}{r}\text { 川崎 No. } 1 \\
\text { No. } 2 \\
\text { No. } 3 \\
\text { 浮島石化 }\end{array}$ & $\begin{array}{r}52.0 \\
62.0 \\
127.0 \\
342.0 \\
--1.0\end{array}$ & & & & 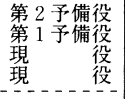 & 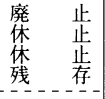 & $\begin{array}{r}0.0 \\
0.0 \\
0.0 \\
342.0 \\
-\end{array}$ & \\
\hline & 計 & 583.0 & 364.0 & 219.0 & 241.0 & & & 342.0 & 22.0 \\
\hline \multirow[t]{2}{*}{ 東燃石油化学 } & $\begin{array}{r}\text { 川崎 No. } 1 \\
\text { No. } 2 \\
\text { No. } 3\end{array}$ & $\begin{array}{r}93.0 \\
130.0 \\
350.0 \\
-.-\end{array}$ & & & & $\begin{array}{l}\text { 第 } 1 \text { 予備役 } \\
\text { 琴 } \\
\text { 役 }\end{array}$ & $\begin{array}{l}\text { 烋 歨 } \\
\text { 残 存 }\end{array}$ & $\begin{array}{r}0.0 \\
0.0 \\
350.0 \\
----\end{array}$ & \\
\hline & 計 & 573.0 & 361.0 & 212.0 & 223.0 & & & 350.0 & 11.0 \\
\hline \multirow[t]{2}{*}{ 新大協和石油化学 } & $\begin{array}{l}\text { 四日市 No. } 1 \\
\text { No. } 2\end{array}$ & $\begin{array}{r}41.3 \\
320.0 \\
\end{array}$ & & & & $\begin{array}{l}\text { 第2 予備役 } \\
\text { 役 }\end{array}$ & 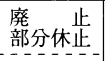 & $\begin{array}{r}0.0 \\
265.9 \\
\end{array}$ & \\
\hline & 計 & 361.3 & 237.0 & 124.3 & 95.4 & & & 265.9 & -28.9 \\
\hline \multirow[t]{2}{*}{ 丸善石油化学 } & $\begin{array}{r}\text { 千葉 No. } 2 \\
\text { No. } 3\end{array}$ & $\begin{array}{r}110.0 \\
395.0 \\
-\end{array}$ & & & & $\begin{array}{l}\text { 第 } 1 \text { 予備役 } \\
\text { 玐 }\end{array}$ & 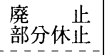 & $\begin{array}{r}0.0 \\
373.0 \\
\end{array}$ & \\
\hline & 計 & 505.0 & 352.0 & 153.0 & 132.0 & & & 373.0 & -21.0 \\
\hline \multirow[t]{2}{*}{ 出光石油化学 } & $\begin{array}{r}\text { 徳山 No. } 1 \\
\text { No. } 2 \\
\text { 千葉 No. } 1 \\
\end{array}$ & $\begin{array}{l}120.0 \\
260.0\end{array}$ & & & $\begin{array}{r}120.0 \\
95.7 \\
-220.0 \\
\end{array}$ & $\begin{array}{l}\text { 現 } \\
\text { 現 }\end{array}$ & $\begin{array}{l}\text { 廢步步 } \\
\text { 部分休設 } \\
\text { 新 }\end{array}$ & $\begin{array}{r}0.0 \\
164.3 \\
220.0 \\
\end{array}$ & \\
\hline & 計 & 380.0 & 354.0 & 26.0 & -4.3 & & & 384.3 & -30.3 \\
\hline 大阪石油化学 & 泉北 No. 1 & 320.0 & 227.0 & 93.0 & 68.0 & 現 & 部分休止 & 252.0 & -25.0 \\
\hline 山陽石油化学 & 水島 No. 1 & 390.0 & 322.0 & 68.0 & 41.5 & 現 & 部分休止 & 348.5 & -26.5 \\
\hline \multirow[t]{2}{*}{ 浮島石油化学 } & $\begin{array}{l}\text { 浮島 No. } 1 \\
\text { 千葉 No. } 2 \\
\end{array}$ & $\begin{array}{r}(312.0) \\
(496.0) \\
-\end{array}$ & & & & $\begin{array}{l}\text { (現 } \\
\text { (現 }\end{array}$ & $\begin{array}{l}\left(\begin{array}{ll}(\text { 残 } & \text { 存 } \\
(\text { 残 }\end{array}\right) \\
\end{array}$ & $\begin{array}{r}(312.0) \\
(496.0) \\
-\end{array}$ & \\
\hline & 計 & $(808.0)$ & & & & & & $(808.0)$ & \\
\hline 合計 & & 6347.7 & 4332.0 & 2015.7 & 2031.3 & & & 4316.4 & 15.6 \\
\hline
\end{tabular}

資料）通商産業省基礎産業局化学課資料「設㣁処理状況」（1986年）(『産構法エチレン設備」ファイル所収） と『化学経済』1980年 8 月臨時增刊号, 30頁上り作成。

注） 1 . 届出能力は 82 年 8 月時点。処理後能力は 86 年 3 月時点。

2. 予備役の区分は, 第 1 予備役 ( 1 力月以内で稼働可能), 第 2 予備役 ( 6 力月以内で稼働可能), 第 3 予備役（稼働の意思がない）である。届出能力には，第 3 予備役の能力は含まれていない。

3. 浮島石油化学の設備能力は, 浮島 1 号機の $1 / 2$ と千葉 2 号機の $5 / 8$ の 466 千トンが三井石油化学 に, 残りの342千トンが 日本石油化学に振り分けられている。 
表 6 エチレン設備枠の融通状況

(単位：千トン /年)

\begin{tabular}{l|r|l|r}
\hline \multicolumn{1}{c|}{ 被融通企業 } & 不足枠 & \multicolumn{1}{|c|}{ 融通企業 } & 融通枠 \\
\hline 三菱油化 & 20.0 & 三菱化成 & 20.0 \\
新大協和石油化学 & 28.9 & 昭和電工 & 20.9 \\
& & 東燃石油化学 & 8.0 \\
丸善石油化学 & 21.0 & 住友化学 & 21.0 \\
出光石油化学 & 30.3 & 三菱油化 & 20.0 \\
& & 大阪石油化学 & 20.0 \\
大阪石油化学 & \multirow{3}{*}{25.0} & 三井石油化学 & 23.0 \\
& & 日本石油化学 & 22.0 \\
山陽石油化学 & \multirow{2}{*}{26.5} & 三菱化成 & 15.0 \\
& & 昭和電工 & 4.5 \\
& & 住友化学 & 4.0 \\
& & 東燃石油化学 & 3.0 \\
\hline 合計 & \multirow{2}{*}{151.7} & & 181.4 \\
\hline
\end{tabular}

資料）通商産業省基䃈産業局化学課資料「設備処理状況」(1986 年)(『産構法エチレン設備』ファイル所収)。
の $\overparen{\mathrm{H}} \mathrm{P}$ 期 達 $\bigcirc$ 要 結 $\mathrm{H}$ E 低 分 $\bigcirc$ 処 果 $\mathrm{P}$ 新: $5 \bigcirc$ 理 得 $\mathrm{P}$ のた高のト量 ら $\mathrm{E}$ 設に密支ン 以 れに備企度援の上 たた新業ポを枠で 枠方設化り受融あ のい等さ汗通つ 余て際れチたをた 剰は、尔たレの行が 分三も直ンでう は菱活鎖間あ都自 自㽜桨でる。合社 息化さ密能卡高 のがれ度力足密 L 同た梠枠架度 |事高の生ポ L 業高工や皆り $\mathrm{D}$ 密子り 原 $\mathrm{P}$ ら度レとこチ Eはポンりのレ の撤リこはた 設退エ $\mathrm{L}$ め めに

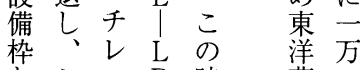

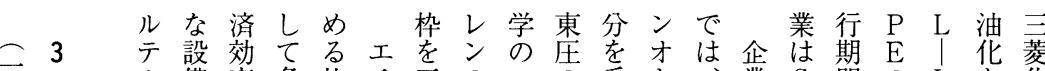

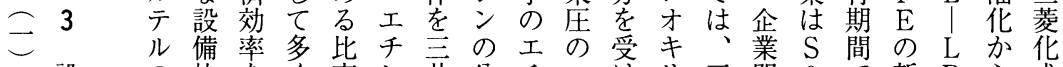

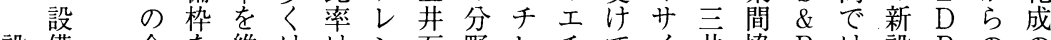
設備合を維ははン石野レチチてイ开協 $\mathrm{B}$ は設 $\mathrm{P}$ の の 備処意企持な、の油でンレ、ド系务の、は $\mathrm{E}$ 枠 $\mathrm{H}$ 処理形業すい不設化は需ン三事云に方設いの融 D 理の 成間るが足備学、要才井業社よ式備両設通 $\mathrm{P}$ 力経、をでた、枠枠に逆のキ東にのるでの社備を $\mathrm{E}$ ル済容融め単べに供に拡开圧関経コ、新の枠受設 テ的易通に独了つ給、大イがす営ンL増共にけ備 ル効にすはでスいし三をド設る行ビ|設同もて枠 の果する重のでてて井図の備提動ナLは事当処の 経るこ要負約はい東る生の携が、 D 認業て理た 済ことと担七、る圧た産堌で代卜 $\mathrm{P}$ ととて負め

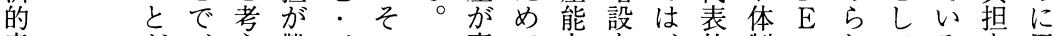
意㤎竞難五の事で力を、的制のれてるを用 義期業 らし\% 融業あを実三なの企て遂。軽い 待界れいで通のる増現井ケ整業い行鹿減ら で全る企あ量集。強し石、備化なさ島しれ き体。業る染約ました油ス。にかれ地たた

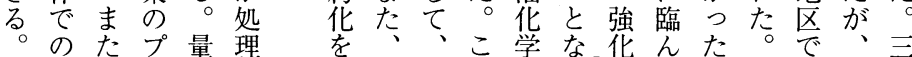
設、ラと量進ポ大れのる敉とでた産のそ菱 備こンし全めリ阪は余。いいめ構 L の化 処のトて体、プ石、剰エうる、法|一成

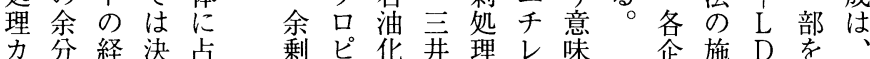




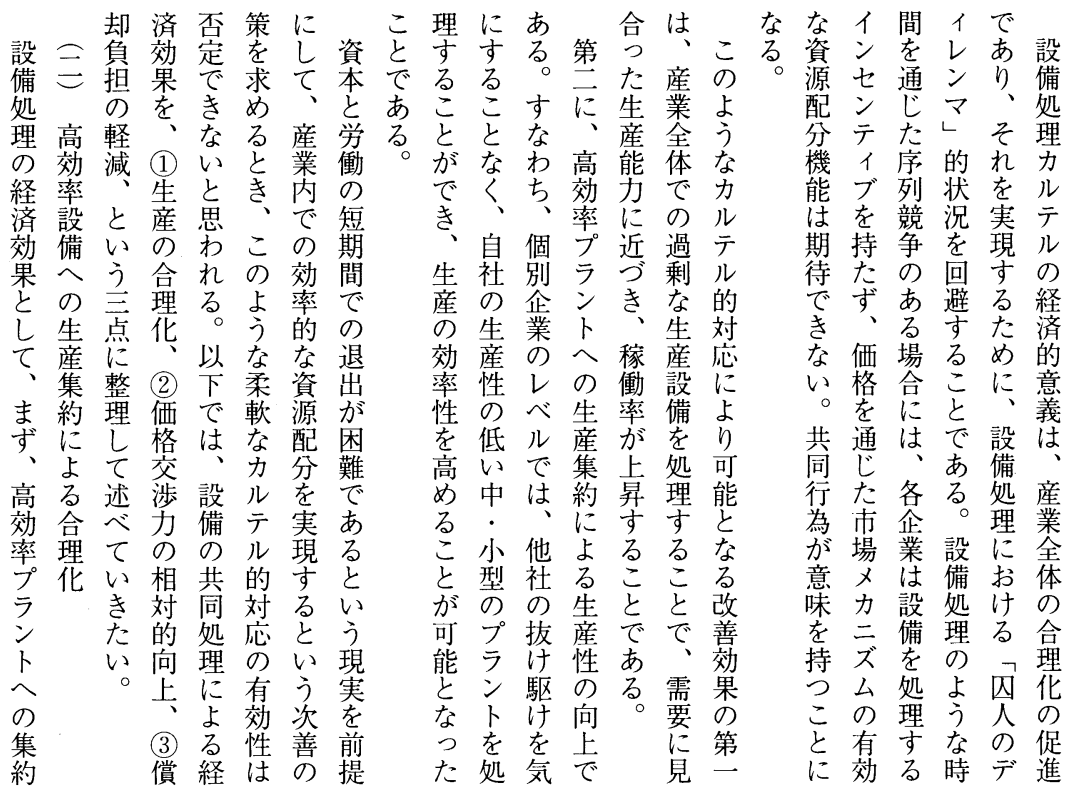

つ列ンラみは力理とな上場三働がるたがは場に 残存未ン規てーで後が次ら昇の \% 率、とめ、、算よ す在満卜模も四主にでにすは八では八、予位る

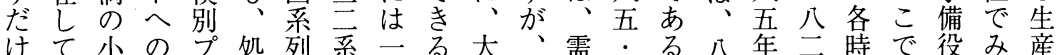
とい型生ラ理へ列四。型こ要一が二の年点はをたの なた プ産ン後と、志プの家\%、年時時に、含現合 つのラ集トに減現場場ラ点にで八の点点挍エ役理 てがン約数は少役へ数ンに対あ五時にでけチ届設化 い、ト化の三し能とはトつする年点はのるるレ出備が る処がが変 $\bar{\bigcirc}$ 減、へいる。の点九工現ン能のあ 。理届よ化万いで少届のて石供最は七場役の力稼る 一後出りをトる二し出生は油給低浮: 平能設を働。 方に能明みン。 $\bar{\bigcirc}$ て能産、化能稼学七均力倸基率表 では务確る台一系い力集次学力働島％のを処準の7 、一゙ととにプ列るで中項企の率石に稼対理に上か 二○一な、上ラを。処ので業制は泪ま働象のし昇ら 万方公る三莽ン数プ理結叙の限出华で率に実てが、 トン列処万て当てンのは劣格背光䍃六て的備認備 ン台、理トいたいトー、れ交景石浮し八いな妈で処 台の現前シるりた数八表る渉に油島て・る效理き理 のプ役に以。のがで工 8 ○力し化工い○。果量るに 中ラ能は上生、は場かのた学場る\%具をを。る 型ン云の 産処、台ら向稼・の。で体測算産っ ラトをで○㚐熊理届ら知步働千四最あ的定定構て

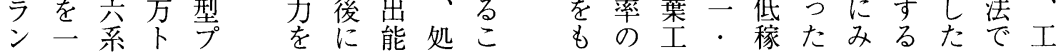


表 7 エチレンの現役能力と稼働率状況

(単位：チトン /年；\%)

\begin{tabular}{|c|c|c|c|c|c|c|c|}
\hline & \multirow[t]{2}{*}{ 工場 } & \multicolumn{3}{|c|}{ 82年 } & \multicolumn{3}{|c|}{ 85年 } \\
\hline & & 現役能力 & 生産量 & 稼働率 & 現役能力 & 生産量 & 稼働率 \\
\hline \multirow[t]{3}{*}{ 三菱油化 } & 四日市 & 370.0 & 203.0 & 54.9 & 210.7 & 213.0 & 101.1 \\
\hline & 鹿島 & 350.0 & 239.0 & 68.3 & 299.0 & 305.0 & 102.0 \\
\hline & 計 & 720.0 & 442.0 & 61.4 & 509.7 & 518.0 & 101.6 \\
\hline 三井石油化学 & 岩国 & 92.0 & 62.0 & 67.4 & 0.0 & 0.0 & - \\
\hline \multirow[t]{3}{*}{ 住友化学 } & 愛媛 & 74.8 & 51.0 & 68.2 & 0.0 & 0.0 & - \\
\hline & 千葉 & 345.0 & 252.0 & 73.0 & 345.0 & 337.0 & 97.7 \\
\hline & 計 & 419.8 & 303.0 & 72.2 & 345.0 & 337.0 & 97.7 \\
\hline 三菱化成 & 水島 & 360.0 & 321.0 & 89.2 & 360.0 & 359.0 & 99.7 \\
\hline 昭和電工 & 大分 & 541.0 & 285.0 & 52.7 & 320.0 & 320.0 & 100.0 \\
\hline 日本石油化学 & 川崎 & 127.0 & 123.0 & 96.9 & 0.0 & 0.0 & - \\
\hline 東燃石油化学 & 川崎 & 480.0 & 253.0 & 52.7 & 350.0 & 300.0 & 85.7 \\
\hline 新大協和石油化学 & 四日市 & 320.0 & 217.0 & 67.8 & 265.9 & 277.0 & 104.2 \\
\hline 丸善石油化学 & 千葉 & 395.0 & 315.0 & 79.7 & 373.0 & 385.0 & 103.2 \\
\hline \multirow[t]{3}{*}{ 出光石油化学 } & 徳山 & 380.0 & 240.0 & 63.2 & 164.3 & 162.7 & 99.0 \\
\hline & 千葉 & - & - & - & 220.0 & 187.3 & 85.1 \\
\hline & 計 & 380.0 & 240.0 & 63.2 & 384.3 & 350.0 & 91.1 \\
\hline 大阪石油化学 & 泉北 & 320.0 & 186.0 & 58.1 & 252.0 & 250.0 & 99.2 \\
\hline 山陽石油化学 & 水島 & 390.0 & 280.0 & 71.8 & 348.5 & 345.0 & 99.0 \\
\hline \multirow[t]{3}{*}{ 浮島石油化学 } & 浮島 & 312.0 & 129.0 & 41.3 & 312.0 & 300.0 & 96.2 \\
\hline & 千葉 & 496.0 & 410.0 & 82.7 & 496.0 & 477.0 & 96.2 \\
\hline & 計 & 808.0 & 539.0 & 66.7 & 808.0 & 777.0 & 96.2 \\
\hline 合計 & & 5352.8 & 3566.0 & 66.6 & 4316.4 & 4218.0 & 97.7 \\
\hline
\end{tabular}

資料）表 3 に同じ。ただし, 出光石油化学・德山工場の85年の生産量は, 德山大学総合経済研究所編『石油化 学産業と地域経済 周南コンビナートを中心として』山川出版社, 2002年, 105頁。

注）1. 現役能力は, 生産能力から, 予備役や休廃止した能力分を控除したものである。 なお，出光石油化学は82年の時点では，まだ千葉にエチレン・プラントを保有していない。

2. 稼働率は, 生産量/現役能力で算出している。 
経営史学 第37巻第 3 号

表 8 設備処理によるエチレンの生産集約

\begin{tabular}{l|r|r|r}
\hline \multirow{2}{*}{} & \multicolumn{2}{|c|}{ 処理前 } & 処理後 \\
\cline { 2 - 4 } & 届出能力 & 現役能力 & 現役能力 \\
\hline 工場数 & 18 & 16 & 14 \\
\hline 生産能力(千トン $/$ 年) & 6347.7 & 5352.8 & 4316.4 \\
\hline プラント数 & 32 & 20 & 14 \\
\hline 30 万ン以上 & $(11)$ & $(11)$ & $(8)$ \\
20万トン台 & $(3)$ & $(3)$ & $(5)$ \\
10万トン台 & $(8)$ & $(4)$ & $(1)$ \\
10万トン未満 & $(10)$ & $(2)$ & $(0)$ \\
\hline 1 プラント当たりの & & & \\
生産能力(千トン $/$ 年) & 198.4 & 267.6 & 308.3 \\
\hline
\end{tabular}

資料）表 5 より作成。

注） 1. 届出能力は, 現役能力に第 1 予備役と第 2 予備役の能 力を含めたものである。

予備役の定義については, 表 5 の注記を参照されたい。

2. 処理前 $=82$ 年 8 月, 処理後 $=86$ 年 3 月。

3. ( )内の数值は内数。
処二ラ 本 部しうト 理号ン来分た占は 負 機卜望 処 結三、 担、はま理果系処 を大、しは、、列理 ク阪三く、処は前 リ石菱なプ理、の ア油油以ラ後年三 ，华化設ンの産系 す学・備卜能主列 る. 鹿処の力 た泉島理生が万ら め北五で産三卜五 で一号あ効 $\vec{\bigcirc}$ 系 あ号機る率万以列 る機、。のト上に がで新こ点シの増 ああ大 か未 プえ 残 る協よら 満 ラて り。和うみとンい の 菱石なてなト 菱油処非つに。 社油华理效た部こ は化学を率も分の 他は.行自四つあ备五 か社日たりあを列 らの市プ、る施の

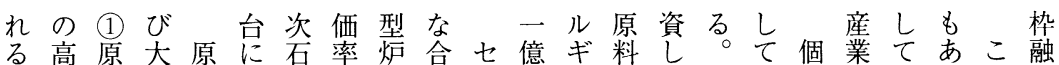
。付料き価低油驾の理ン意、原て浮通別全、るの通 八加子く率卡危示導化夕と原単い島産企体三がよを 五価フ低のし機さ入を|な単位る石大業の○、う受 年值开下低て以れ等推各つ位の工油臣レ生万全にけ の化価す下い降てを進社た汿の向チ华のべ産卜体、て 時 格る傾る九い実しは。向上レ学承ル性ンと部処 点フの傾向。○る施、国上世ンは認のは以し分理 まア低向は\%。しコ際を原製、を事上上て処負 でイ下が、をたた競通料造三受業昇のみ理担

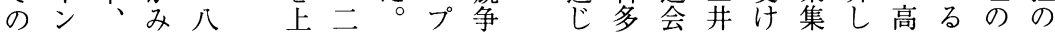
原化 (2) ら五回社表レ力た稼社石た約た効とた軽 価生れ年つ単 9 \% 合化で油浮化。率め減 率と産るまて純にサ改理にあ化島で祭旧にを のいの。市平は、善 低う合原でた均、のに 下主理価二段の二改向

に関の华率段落八売二善け

し要 (3) 低 L 四高ンガ残 て因脱下、年原多存 はが沉要八加価 I 夕設 主用畜六ら率の 1 備 原に化と年はは売ビの 料考 \|しか.八、上積 ナえ製てら $○$ 第高や極 フら品は再 \% 三原新的

僌るる。学名は 果原浮旦华望 は料島本学ま 、コ石石のし 金ス油油ヶい 額卜化化 I 事 ベの学学 ス 業 1 低にのが提 ス減市両好携 で、け社例計 年エる、がと画
生 式 経 L 産の済た 設 中効上 備・率志 に小がの 集 型一措 約 70 部 置 化 ラ損で すンなあ。 るトわる36 こをれ と処た で理点 
表 9 売上高原価率の推移

\begin{tabular}{l|r|c|c|c|c|c}
\hline & \multicolumn{1}{|c|}{82 年 } & 83 年 & 84 年 & 85 年 & 86 年 & 87 年 \\
\hline 三菱油化 & 95.2 & 89.6 & 85.8 & 85.6 & 82.7 & 74.2 \\
三井石油化学 & 87.9 & 84.2 & 80.3 & 78.4 & 74.1 & 69.3 \\
住友化学 & 85.8 & 82.4 & 79.8 & 84.0 & 81.2 & 78.7 \\
三菱化成 & 88.8 & 87.0 & 84.4 & 84.4 & 81.0 & 78.5 \\
昭和電工 & 85.1 & 83.3 & 80.1 & 82.2 & 80.0 & 79.7 \\
日本石油化学 & 96.1 & 92.8 & 91.5 & 92.1 & 87.9 & 86.4 \\
東燃石油化学 & 92.1 & 93.5 & 92.4 & 92.4 & 89.1 & 85.7 \\
新大協和石油化学 & 102.0 & 93.5 & 90.5 & 92.7 & 89.2 & 86.0 \\
丸善石油化学 & 99.2 & 93.2 & 93.6 & 91.3 & 89.0 & 84.3 \\
出光石油化学 & 90.5 & 88.6 & 88.1 & 88.0 & 83.7 & 83.9 \\
大阪石油化学 & 97.8 & 93.7 & 93.7 & 94.8 & 94.2 & 93.6 \\
山陽石油化学 & 99.3 & 97.8 & 97.4 & 98.4 & 97.6 & 96.3 \\
\hline \multicolumn{1}{c|}{ 平均 } & 93.3 & 90.0 & 88.1 & 88.7 & 85.8 & 83.1 \\
\hline
\end{tabular}

資料）『化学経済』1984年 9 月号, 56頁, 1986年 8 月号, 24-25頁, 1988年 9 月号, 78 頁。

注）平均值は, 12 社の売上高原価率の単純平均である。

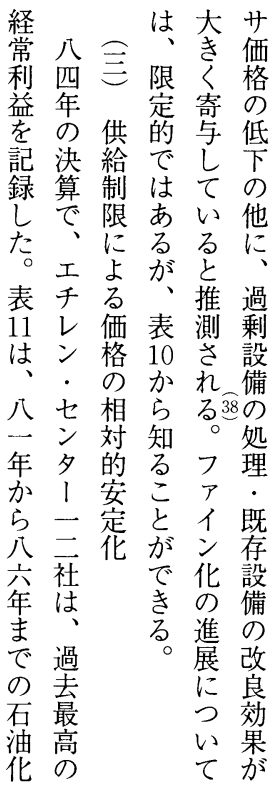

表10 ファイン化の進展状況

\begin{tabular}{|c|c|c|c|}
\hline & 82 年 & 87年 & ファイン化製品の内容 \\
\hline 三菱化成 & 12 & 31 & 機能商品（情報機材, 電子機材, 医農薬等) \\
\hline 住友化学 & 29 & 31 & 製品化学品, 農業化学品（肥料を除く）等 \\
\hline 昭和電工 & 15 & 25 & 情報機材，電子機材，バイ才関連品等 \\
\hline $\begin{array}{l}\text { ダウ・ケミカル } \\
\mathrm{ICI}\end{array}$ & $\begin{array}{c}36 \\
\text { n. a. }\end{array}$ & $\begin{array}{l}48 \\
35\end{array}$ & $\begin{array}{l}\text { 産業用スペシャリティー（電子材料他）等 } \\
\text { 医農薬, その他機能製品 }\end{array}$ \\
\hline
\end{tabular}

資料）通商産業省基礎産業局「我が国石油化学工業施策の推移について」(1989年), 32 頁。

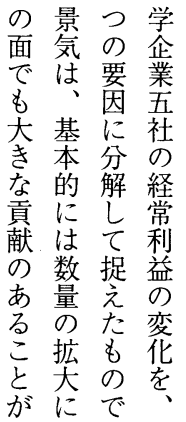

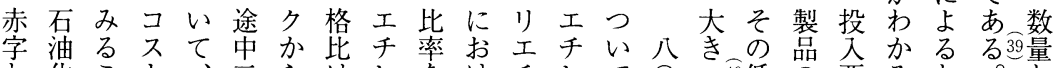

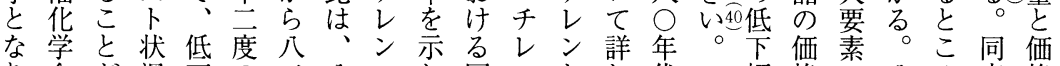

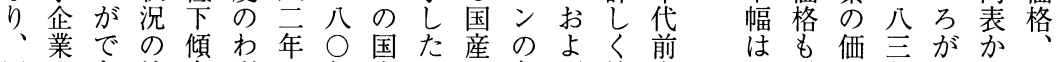
同のき持向ずの年産のナ各び検半 年多る続をか一のナがフ価低討の 二人。的示な○初〉図》格: 寸価 ○が八な上去め等1価と高る格 月深二悪て昇まのとで格同密た動 か刻年华书をでピのあと時度め向 らなはをり除、、価る画の点ポ、に 投低格年大方固

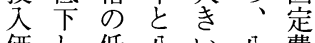
価し低八い八費 格て下四が四と のいに年、年い 方る伴は価のう がが心、格好三 
経営史学 第37巻第 3 号

表11 経常利益変化の要因分析

対象企業 : 三萲油化, 三井石油化学（2 社）

(単位：百万円)

\begin{tabular}{|c|c|c|c|c|c|c|c|c|c|c|c|c|}
\hline \multirow{2}{*}{ 暦年 } & \multicolumn{3}{|c|}{ 洒格効果 } & \multicolumn{3}{|c|}{ 数量効果 } & \multicolumn{3}{|c|}{ 複合効果 } & 固定費 & \multicolumn{2}{|c|}{ 経常利益 } \\
\hline & $\triangle 0 \times Q^{\prime}$ & $\Delta I \times V^{\prime}$ & 差分 & $\Delta Q \times 0^{\prime}$ & $\Delta V \times I^{\prime}$ & 差分 & $\triangle O X \Delta Q$ & $\triangle I X\lrcorner V$ & 差分 & $\Delta F$ & $\Delta \pi$ & $\pi$ \\
\hline 1981年 & $-27,936$ & $-16,523$ & $-11,413$ & $-10,308$ & 7.746 & $-18,054$ & 418 & -253 & 671 & -373 & -28.421 & -18.342 \\
\hline 1982年 & $-1,789$ & -685 & $-1,105$ & $-10,974$ & $-2,365$ & $-8,609$ & 30 & 3 & 27 & $-7,383$ & -2.305 & $-20,647$ \\
\hline 1983年 & $-16,560$ & $-20,956$ & 4,395 & 35.514 & 10,359 & 25,154 & -921 & -440 & -481 & 4,034 & 25.030 & 4,383 \\
\hline 1984年 & $-13,383$ & $-24,004$ & 10,621 & 49,078 & 19,155 & 29,923 & $-1,001$ & -953 & -48 & 18.182 & 22,316 & 26.699 \\
\hline 1985年 & -13.076 & $-10,308$ & $-2,768$ & $-4,036$ & $-19,899$ & 15,863 & 76 & 430 & -354 & 16.018 & -3.279 & 23.420 \\
\hline 1986年 & $-88,536$ & $-93,063$ & 4,527 & $-98,182$ & $-80,061$ & $-18,121$ & 12,894 & 16,664 & $-3,770$ & -12.553 & -4.809 & 18,611 \\
\hline
\end{tabular}

対象企業: 三菱油化, 三井石油化学, 住友化学, 三菱化成, 昭和電工（5 社）（単位：百万円）

\begin{tabular}{|c|c|c|c|c|c|c|c|c|c|c|c|c|}
\hline \multirow{2}{*}{ 暦年 } & \multicolumn{3}{|c|}{ 価格効果 } & \multicolumn{3}{|c|}{ 数量効果 } & \multicolumn{3}{|c|}{ 複合効果 } & \multirow{2}{*}{$\frac{\text { 固定費 }}{\Delta \mathrm{F}}$} & \multicolumn{2}{|c|}{ 経常利益 } \\
\hline & $\triangle 0 \times Q^{\prime}$ & $\Delta \mathrm{I} \times \mathrm{V}^{\prime}$ & 差分 & $\Delta Q \times 0^{\prime}$ & $\Delta V \times I^{\prime}$ & 差分 & $\triangle 0 \times \perp Q$ & $\triangle I X J V$ & 差分 & & $\Delta \pi$ & $\pi$ \\
\hline 1981年 & $-41,594$ & $-24,583$ & $-17,010$ & $-127,534$ & $-72,326$ & $-55,208$ & 2.041 & 940 & 1,100 & 5,916 & -77.027 & $-15,588$ \\
\hline 1982年 & -19.777 & $-3,637$ & $-16,139$ & $-38,558$ & $-42,633$ & 4,075 & 313 & 86 & 227 & 2,438 & $-14,283$ & $-29,871$ \\
\hline 1983年 & $-51,091$ & $-53,265$ & 2.174 & 95,786 & 27,701 & 68,085 & $-2,061$ & -844 & -1.217 & -682 & 69.720 & 39.849 \\
\hline 1984年 & $-43,028$ & $-43,287$ & 260 & 237,042 & 117,547 & 119,495 & $-4,220$ & -2.954 & -1.266 & 35.327 & 83,163 & 123.012 \\
\hline 1985年 & $-36,130$ & $-28,901$ & $-7,229$ & $-4,514$ & 13,742 & $-18,257$ & 63 & -221 & 284 & 11,045 & $-36,250$ & 86,762 \\
\hline 1986年 & -191.436 & $-264,042$ & 72,605 & $-406,725$ & $-320,832$ & -85.893 & 30,339 & 47.634 & -17.295 & $-7,350$ & $-23,230$ & 63,332 \\
\hline
\end{tabular}

資料）日本銀行調查統計局『物価指数年報』；各社『有価証券報告書総覽』より作成。

注） 1. 対象企業は, 三菱油化 $(1-12$ 月), 三井石油化学工業 $(4-3$ 月), 三菱化成 $(2-1$ 月), 住友化 学工業 $(1-12$ 月), 昭和電工 $(1-12$ 月) の 5 社。

2. 経常利益変化の要因分解は次式で算出した。

$\mathrm{O}$ : 産出物価指数, $\mathrm{I}$ ：投入物価指数, $\mathrm{Q}$ : 売上高 $/ \mathrm{O}, \mathrm{V}$ : 変動費 $/ \mathrm{I}, \mathrm{F}$ : 固定費, $\pi$ : 経常利 益（’は前年を意味）

$$
\begin{aligned}
\Delta \pi & =\mathrm{OQ}-\mathrm{IV}-\mathrm{F}-\pi \\
& =\left(\mathrm{O}^{\prime}+\Delta \mathrm{O}\right)\left(\mathrm{Q}^{\prime}+\Delta \mathrm{Q}\right)-\left(\mathrm{I}^{\prime}+\Delta \mathrm{I}\right)\left(\mathrm{V}^{\prime}+\Delta \mathrm{V}\right)-\left(\mathrm{F}^{\prime}+\Delta \mathrm{F}\right)-\pi, \\
& =\left(\Delta \mathrm{OQ}^{\prime}-\Delta \mathrm{IV}\right)+\left(\Delta \mathrm{QO}^{\prime}-\Delta \mathrm{VI}^{\prime}\right)+(\Delta \mathrm{O} \Delta \mathrm{Q}-\Delta \mathrm{I} \Delta \mathrm{V})-\Delta \mathrm{F}
\end{aligned}
$$

3. 2 社の分析では, 物価指数は, 製造業総合指数に占める割合に基づき, 石油化学基硙製品と合成樹脂 の指数の加重平均値を用いた。これに対し， 5 社の計算では，化学製品の物価指数を利用している。

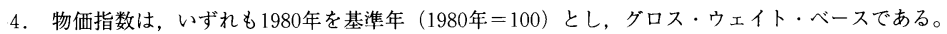

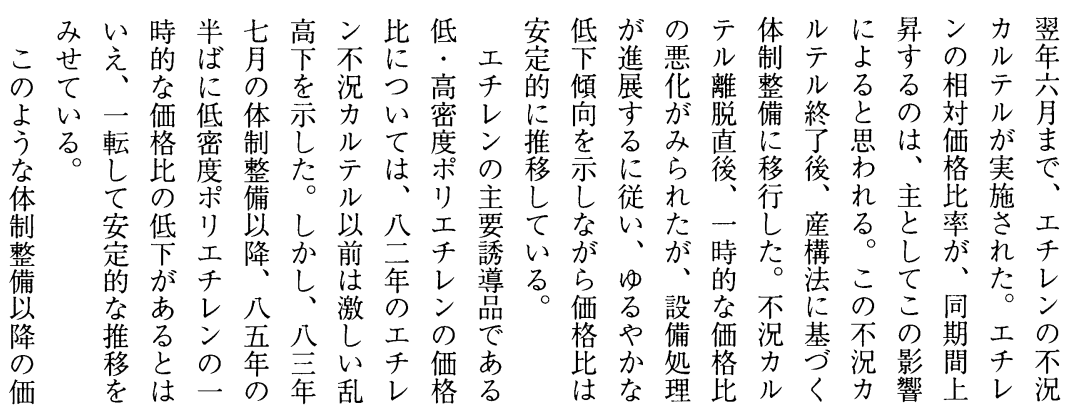




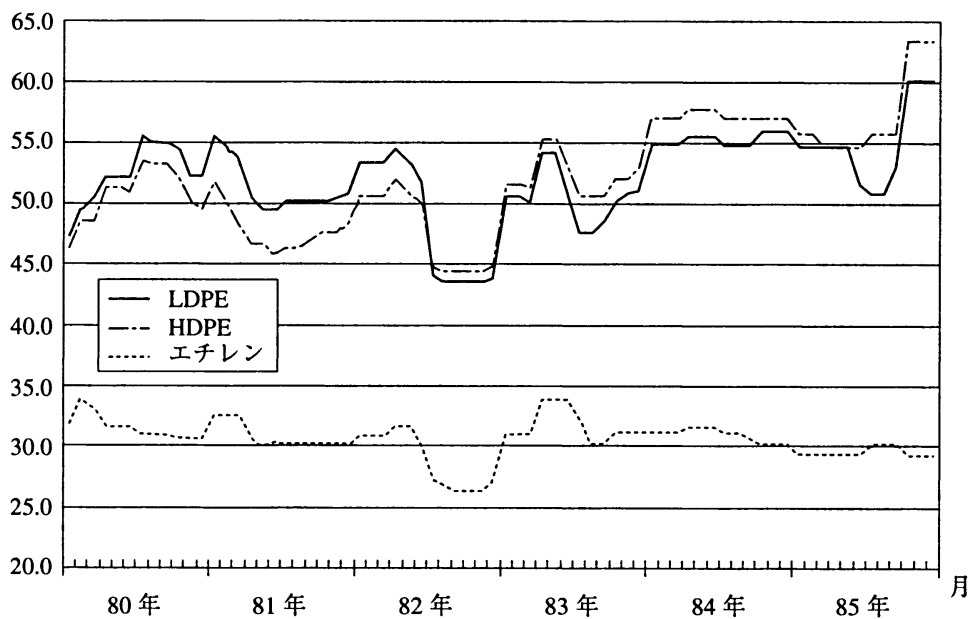

資料）『クォータリー日経商品情報』各号。

注）価格比：エチレン・LDPE・HDPEの各価格（円／kg）／国産ナフサ価格（円／kl）×10000

図 1 エチレン・LDPE・HDPE /国産ナフサ価格比

表12 設備処理の有無による稼働率格差

\begin{tabular}{l|c|c|c}
\hline & 処理後稼働率 $(\mathrm{A})$ & 未処理稼働率 $(\mathrm{B})$ & 格差 $(\mathrm{A}-\mathrm{B})$ \\
\hline エチレン & 97.7 & 78.8 & 18.9 \\
低密度ポリエチレン & 99.2 & 72.2 & 27.0 \\
高密度ポリエチレン & 100.8 & 78.7 & 22.1 \\
ポリプロピレン & 95.1 & 99.8 & -4.7 \\
エチレンオキサイド & 83.7 & 70.0 & 13.7 \\
スチレンモノマー & 90.9 & 81.8 & 9.1 \\
\hline
\end{tabular}

資料）表 3 に同じ。

注）処理後稼働率：85年生産量 $/ 85$ 年現役能力。未処理稼働率 : 85 年生産量 $/ 82$ 年現役 能力。ただし，スチレンモノマーの未処理稼働率の能力は 84 年時点。

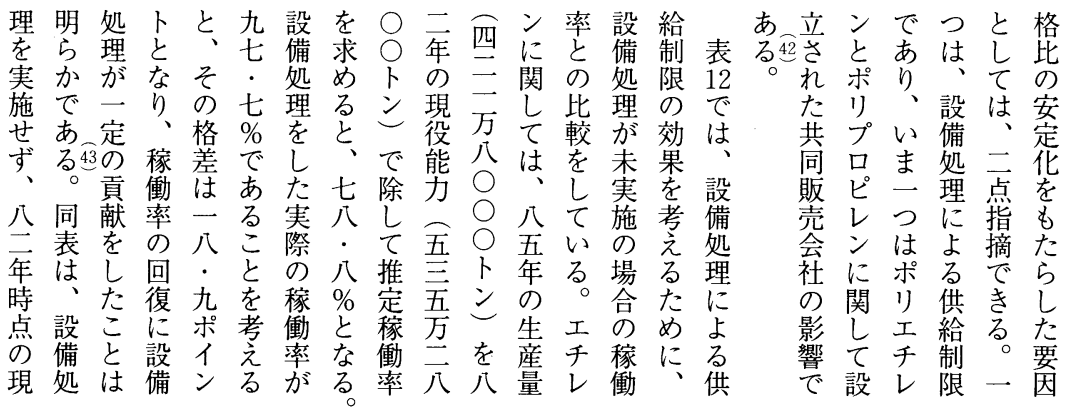


経営史学 第37巻第 3 号

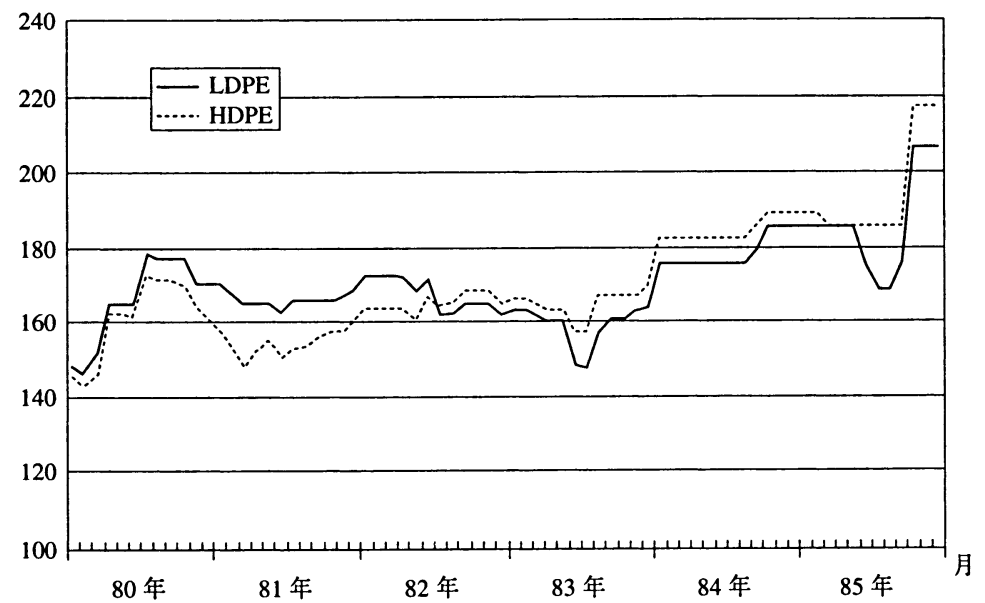

資料）『クォータリー日経商品情報』各号。

注）価格比：LDPE・HDPEの各価格／エチレン価格 $\times 100$

図 2 誘導品／エチレン価格比

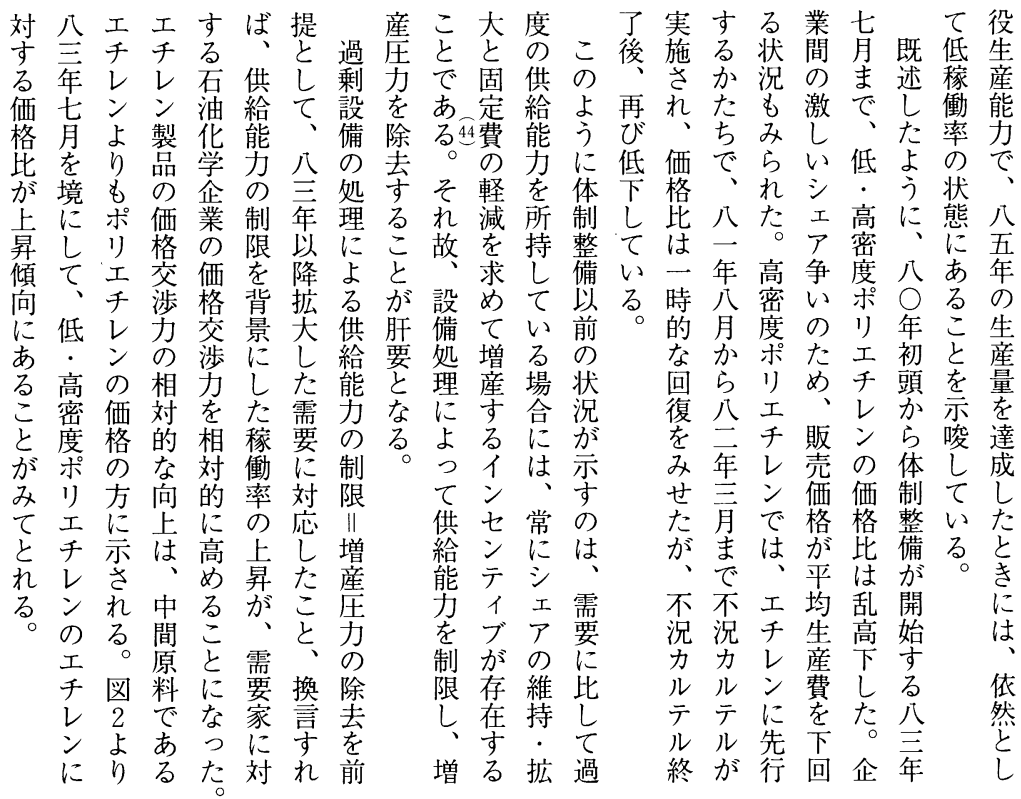


表13 固定費変化の寄与度分解

\begin{tabular}{|c|c|c|c|c|c|c|c|c|c|c|c|}
\hline \multirow{2}{*}{ 暦年 } & \multirow{2}{*}{$\begin{array}{l}\text { 固定費 } \\
\text { 前年比 }\end{array}$} & \multicolumn{2}{|c|}{ 販売·管理費 } & \multicolumn{2}{|c|}{ 労務費 } & \multicolumn{2}{|c|}{ 滅価償却費 } & \multicolumn{2}{|c|}{ 営業外差損 } & \multicolumn{2}{|c|}{ その他経費 } \\
\hline & & 前年比 & 寄与度 & 前年比 & 寄与度 & 前年比 & 寄与度 & 前年比 & 寄与度 & 前年比 & 寄与度 \\
\hline 1981年 & 0.91 & 4.71 & 1.50 & 1.29 & 0.20 & 1.09 & 0.13 & -13.97 & -2.01 & 4.20 & 1.09 \\
\hline 1982年 & 0.37 & 4.00 & 1.32 & -3.12 & -0.49 & 4.83 & 0.59 & 4.89 & 0.60 & -6.15 & -1.65 \\
\hline 1983年 & -0.10 & 3.18 & 1.09 & -7.70 & -1.17 & -1.79 & -0.23 & 1.98 & 0.25 & -0.18 & -0.05 \\
\hline 1984年 & 5.39 & 10.65 & 3.76 & 4.94 & 0.69 & -6.58 & -0.83 & -0.56 & -0.07 & 7.39 & 1.85 \\
\hline 1985年 & 1.60 & 3.03 & 1.12 & 4.72 & 0.66 & -1.21 & -0.14 & -10.30 & -1.27 & 4.80 & 1.22 \\
\hline 1986年 & -1.05 & 3.52 & 1.32 & 5.86 & 0.84 & 5.62 & 0.61 & -25.37 & -2.76 & -4.05 & -1.06 \\
\hline
\end{tabular}

資料）各社『有価証券報告書総覧』。

注）1。対象企業は, 三菱油化 $(1-12$ 月), 三井石油化学工業 $(4-3$ 月), 三菱化成 $(2-1$ 月), 住友化 学工業 $(1-12$ 月), 昭和電工 $(1-12$ 月) の 5 社。

2. 寄与度は次式により算出した。寄与度 $=($ 当年の実数 - 前年の実数 $) /($ 前年の固定費の実数 $) \times 100$

3. 各企業の『有価証券報告書総覽』の記載上の制約から, 固定費の仕訳に関しては以下の限界を残して いる。

(1)「販売·管理費」では，『有価証券報告書総覧」に記載されている「販売費及び一般管理費」の全額 を計上した。このため，本来は変動費に区分すべき，荷造費や運搬費等が固定費に含まれている。 (2)「その他経費」の項目には，本来変動費に区分すべき，水道光熱費等が含まれている。

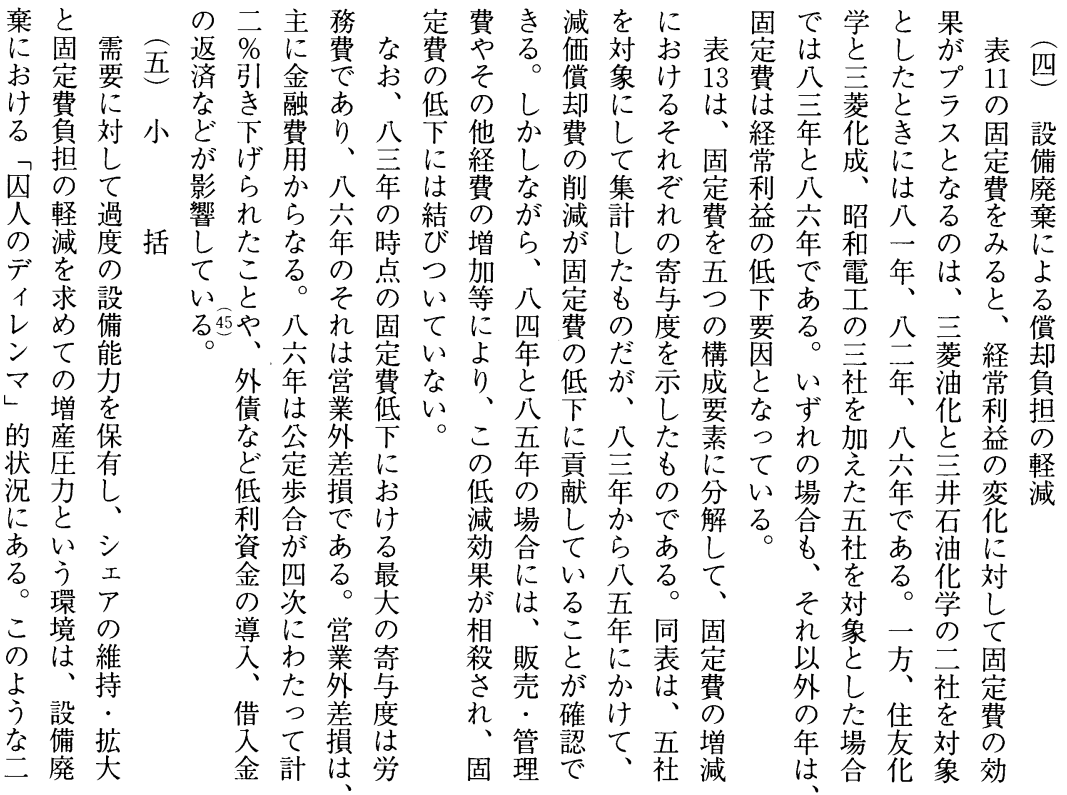




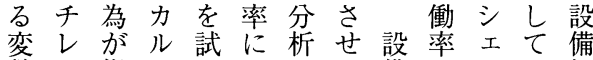

数ン指テ少つでる備のアい処こ

での示ルてい堀モ処二とき理で設

あ 三さ・いて内 ヴ理つ設たのは備

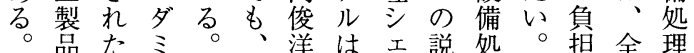

ま㤎、そ設氏穴明理基が製の

た二チがの備がすを変率本ど品統 のレ導際棌で、数を的の! 計

設值ン文而用に設に、なよ全分

備を、さ共アし特備回八考う王析

処々低れ同とて安洲帚之に場

理り密る行稼い法エし年はなを

の、度。為働る的にアよの、さ対

対々禾力の率。基とう時各れ象

象れリル有の本方稼と点製てに

外以エテ無二稿く働いで品いし

で外チルの変で合率うののたて

あのレ・効数は繊のも設工の総

る製ンダ果に、産二の備場か合

ポ品、ミを回さ業つで能ごを的

リが高门確帰らののあ北と統に

プ○密は認さに設変るシの計み

口の度、吉せ設備数。エ設的た

ピ值ポ共るる備処に推自々備にと

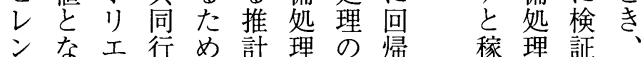

格固与理産 理律 窔定しは集の背 渉費た減約 共反 力の。価化同的 を低さ償に行な 向減ら却よ為状 上にに費りは況 さと、の、大を せど供低産き打

たま給滅業な開 ず能を通体意し 、为通体味問 需制て 合も題 要限、理つの 家老企华た解 に背業加。決 対景の䚄ずは るし務し、か 石た状た高る 油稼況。効た 华働のま率め 学率改た設に 企の善、備 業上に設へ設 の昇も備の備 価は寄処生処

のプ持プグドの の てで界こてに件高れの このつの設ルと指袁いのとと設卜基表は效設以影 と場こ場備、页示チ 15 る事比か備はづ 14 、率備外響 は合と合処プチをととと前へら処比いか設設のにを に年は理にレ得ン表考調ても理較てら備備処は除 力は特、率分ンて低 16 整、率的処、シへ理 ○去 ル、徵設を㳻 テ設的備被て, な高版可い同つ理シ製ア集準值る ル備でシ説推マい高共る能設行い負工品に約がをた

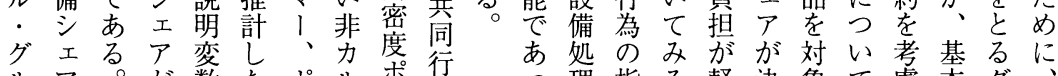

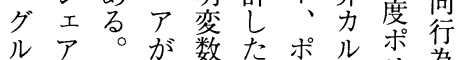

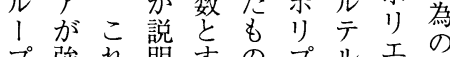

プ強れ琞专のプルエの つ理指る軽決象て慮本多 た率示と減めにはし的ミポ かをを、さらみ正たに、リ は説対を推あ比レ゙示 明し 持計るレルンをを

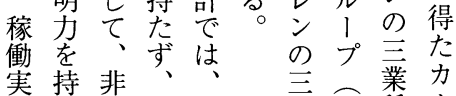

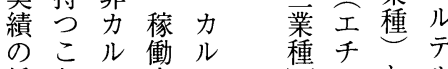
低と率テ連とと、ル

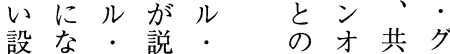
備るグ明グ 二キ同ル

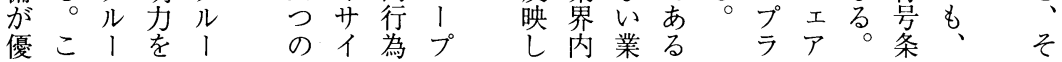
ど示得力れれた のは変 プ うすたルててと稼で能数口 かこ業テいいき働あ力を次 がと界儿るる、率れシ組レ 、がの・こが基にばエみン 設確方多と、本つ、ア込に 備認がミが稼的い説にんの 処で、! 確㗢にて明基でみ 理きそが認率はは変づい一率るう有での設負数きる47の に。で意き高備と怒うす。值 
表14 設備処理の回帰分析 I（全製品対象）

設備処理シェア サンプル数 $=77$. カルテル・ダミー $=45$. PP ダミー= $=14$. (ダミー変数は 1 の值をとる数 $)$

\begin{tabular}{|c|c|c|c|c|c|c|c|}
\hline & (1) & (2) & (3) & (4) & (5) & (6) & (7) \\
\hline \multirow{2}{*}{ 定数項 } & -0.923 & $16.751^{* * *}$ & $6.353^{* * *}$ & $11.011^{* *}$ & $10.979^{* *}$ & $10.711^{* *}$ & $12.281^{* *}$ \\
\hline & -0.298 & 3.400 & 2.513 & 2.253 & 1.729 & 2.182 & 1.823 \\
\hline \multirow{2}{*}{ 設備シェア } & $0.942^{* * *}$ & & & $1.159^{* * *}$ & $1.160^{* * *}$ & $1.135^{* * *}$ & $1.090^{* * *}$ \\
\hline & 2.739 & & & 3.471 & 3.347 & 3.344 & 2.966 \\
\hline \multirow{2}{*}{ 稼働率 } & & $-0.163^{* *}$ & & $-0.214^{* * *}$ & $-0.214^{* * *}$ & $-0.202^{* * *}$ & $-0.205^{* * *}$ \\
\hline & & -2.214 & & -3.056 & -2.890 & -2.693 & -2.697 \\
\hline カルテル. & & & 0.113 & & 0.027 & & -1.334 \\
\hline ダミー & & & 0.034 & & 0.008 & & -0.332 \\
\hline PP ダミー & & & & & & -2.061 & -2.992 \\
\hline $\mathrm{ad}-\mathrm{R}^{2}$ & 0.079 & 0.049 & -0.013 & 0.171 & 0.160 & 0163 & $015 ?$ \\
\hline
\end{tabular}

設備処理率 サンプル数 $=77$. カルテル・ダミー $=45 . \quad$ PP ダミー $=14$. 処理率ダミー $=12$.

\begin{tabular}{lccccccc}
\hline & $(1)$ & $(2)$ & $(3)$ & $(4)$ & $(5)$ & $(6)$ & $(7)$ \\
\hline \multirow{2}{*}{ 定数項 } & 6.872 & $55.012^{* * *}$ & 3.473 & $47.147^{* * *}$ & $21.051^{*}$ & $43.313^{* * *}$ & $23.803^{*}$ \\
& 0.960 & 5.206 & 0.765 & 3.953 & 1.450 & 3.676 & 1.577 \\
\hline \multirow{2}{*}{ 設備シエア } & 0.901 & & & $0.936^{*}$ & $1.536^{* *}$ & 0.806 & $1.389^{* *}$ \\
& 1.220 & & & 1.392 & 2.279 & 1.222 & 1.960 \\
\hline \multirow{2}{*}{ 稼働率 } & & $-0.593^{* * *}$ & & $-0.596^{* * *}$ & $-0.434^{* * *}$ & $-0.479^{* * *}$ & $-0.415^{* * *}$ \\
& & -3.990 & & -4.033 & -2.864 & -3.110 & -2.690 \\
\hline カルテル & & $19.580^{* * *}$ & & $17.439^{* * *}$ & & $14.600^{* *}$ \\
ダミー & & 3.367 & & 2.888 & & 2.007 \\
\hline \multirow{2}{*}{$\mathrm{PP}$ ダミー } & & & & & $-16.037^{* *}$ & -6.206 \\
& & & & & & -2.134 & -0.702 \\
\hline \multirow{2}{*}{ 处理率ダミー } & $90.015^{* * *}$ & $68.106^{* * *}$ & $83.474^{* * *}$ & $72.841^{* * *}$ & $78.937^{* * *}$ & $75.269^{* * *}$ & $78.887^{* * *}$ \\
\hline \multirow{2}{*}{ adー $\mathrm{R}^{2}$} & 9.785 & 7.727 & 10.565 & 7.752 & 8.578 & 8.141 & 8.542 \\
\hline
\end{tabular}

資料）表 3 に同じ。

注) 1. 次の 3 工場は, 82年の時点では未榢働であるため, 分析対象からは除外されている。

出光石油化学・千葉 (エチレン), 三井石油化学・岩国 (LDPE), 泉北ポリマー・堺 (PP)。

2. 各変数の定義は, 次の通り。

設備処理シエア：工場別・製品別処理量 $/$ 製品別総処理量 $\times 100$

設備処理率：工場別・製品別処理量／工場別・製品別 82 年生産能力 $\times 100$

設㣁シエア：工場別・製品別 82 年生産能力/製品別 82 年総生産能力 $\times 100$

稼働率：工場別・製品別 82 年生産量 $/$ 工場別・製品別 82 年生産能力 $\times 100$

ただし，スチレンモノマーに限り，84年の数值を用いている。

3. 各項目下段の数值は, $\mathrm{t}$ 值。有意水準：***1\%; ${ }^{* *} 5 \% ;{ }^{*} 10 \%$

4. 設備処理率を被説明変数とする推計では, 処理率が $100 \%$ 示す工場には, 1 の值をとるダミー変数 を用いている。处理率タミーを除いた場合, 全ての推計において, 設備シェアの係数は負になるが, 統計的には有意ではない。このような符号の逆転は, 設備シェアの相対的に小さい一部工場が処理率 $100 \%$ という高い值を示す影響による。 
経営史学 第 37 巻第 3 号

表15 設備処理の回帰分析 II（カルテル・グ ループ対象）

設備処理シェア サンプル数 $=45$.

\begin{tabular}{|c|c|c|c|}
\hline & (1) & (2) & (3) \\
\hline \multirow{2}{*}{ 定数項 } & $3.961^{* *}$ & $13.858^{* * *}$ & $11.448^{* * *}$ \\
\hline & 2.029 & 5.585 & 4.775 \\
\hline \multirow{2}{*}{ 設備シェア } & $0.376^{*}$ & & $0.739^{* * *}$ \\
\hline & 1.416 & & 3.088 \\
\hline \multirow{2}{*}{ 稼働率 } & & $-0.129^{* * *}$ & $-0.173^{* * *}$ \\
\hline & & -3.131 & -4.297 \\
\hline ad $-R^{2}$ & 0.022 & 0.167 & 0.305 \\
\hline \multirow[t]{2}{*}{ 設備処理率 } & \multicolumn{3}{|c|}{ サンプル数 $=45$. 処理率ダミー $=8$. } \\
\hline & (1) & (2) & (3) \\
\hline \multirow{2}{*}{ 定数項 } & $16.995^{*}$ & $68.718^{* * *}$ & $59.400^{* * *}$ \\
\hline & 1.386 & 4.777 & 3.495 \\
\hline \multirow{2}{*}{ 設備シェア } & 0.999 & & 1.425 \\
\hline & 0.652 & & 1.028 \\
\hline \multirow{2}{*}{ 稼働率 } & & $-0.717^{* * *}$ & $-0.739^{* * *}$ \\
\hline & & -3.198 & -3.282 \\
\hline 処理率 & $80.087^{* * *}$ & $57.742^{* * *}$ & $63.697^{* * *}$ \\
\hline ダミー & 6.415 & 5.316 & 5.177 \\
\hline $\mathrm{ad}-\mathrm{R}^{2}$ & 0.540 & 0.626 & 0.627 \\
\hline
\end{tabular}

八率と社のてのル先 至考の説い高 l的 年示え稼明るいプに かすら働力と一の処 らにれ率が思部推理 八もる年が効わの計さ 六加平力れ企結れ 年か安均をる業果て のわ値し失。にはい 間 ら輸て う加、、る ず入高のえ設処事 赤品くはて備理実 字同の、、、処云と を業影稼八非理工二 継 界響働四力のア致 続のを率年ル多の守 し経強ののテ場る て常く格スルが合 い利受差千・集とま る益け唯レグ中同た はた縮ンルし様 た小モはたに非 八めし, プ事为 四にてマで態設ル 年、い।、俑テ を高る業稼反沙ル 除稼た界働映工。 き働め各率しアグ

成率第をににデ

の害よレ一稿

引に現りンにのの四

き、思、マ、主 下こた生し設要お

低異理式さ担工たる内化融げの旡的備な

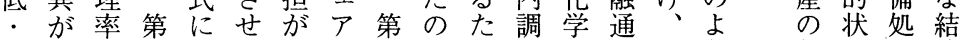
高みに四よる減に至もめ整のなべう集況理論 密ら関にると少基に事、市産どスな約かには 度れ守、経いし宁実こ方業設卜共 ポたる共済うてき設での式事備! 同 リ。説同損結おつ備あよと情処シ行 工共明行失果り主処るう言に理工為 千共要為はに、も理。な党即基予の

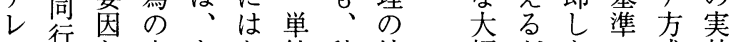
ン為と実あな純稼結幅がたの式効 業為、施るつに働果な、選緩の性 界をその程てシ率は譲共択和無を で実の有度いェの、歩同でが修担 は施達無回なア程基交行あ試正保 、成に避いに度本修為りみ採导 主た率よさ。比に的正の、ら用る と土にり、れプ茢よに架泰柔れ没た

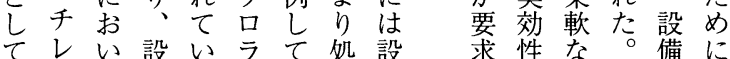

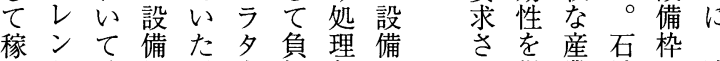
働と差処。方担負 シ
化 5 お 脱け次 償却るの 却古共四 負る同点 担の行に のに為整 軽大は理 減き、で な設き 価意備る 格味 処 の が理 相あの 对 つ 的た因 安 人 


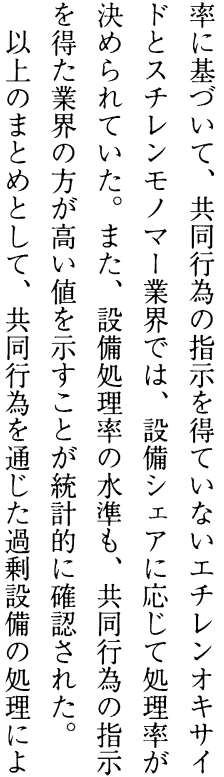

実当売の整 的時のグで 手石理 Iる 段 油化 プ と化をに産 は学実分構 考業現け、法 え業委、て らにるそは れおとの ないいグ業 かてうル界 つ、政了。瓷 た業手を本処裂測を高基 めの段基や理よさ 度つ で合が礎生のうれ国成い も併採と産かとる際長て あ等用し関たし中環を実 るにさて係ちた、境前施 。よれ生にを産その提 産るた産基と業れ恋とれ 構集。とうう調に化した 法約こ流いた整対とて設 で化れ通て設政応需確備 はがは・複備策し要立の 、現、販数調でたの竞
表16 設備処理の回帰分析 III (非カルテル・グループ対象)

設備処理シェア サンプル数 $=32$. PP ダミー $=14$.

\begin{tabular}{lcccc}
\hline & $(1)$ & $(2)$ & $(3)$ & $(4)$ \\
\hline \multirow{2}{*}{ 定数項 } & -6.075 & $23.462^{* *}$ & 10.701 & 11.590 \\
& -0.872 & 1.874 & 0.801 & 0.832 \\
\hline \multirow{2}{*}{ 設備シェア } & $1.326^{* *}$ & & $1.305^{* *}$ & $\begin{array}{l}1.235^{* *} \\
\text { 2.076 }\end{array}$ \\
\hline \multirow{2}{*}{ 稼働率 } & & $-0.236^{*}$ & $-0.229^{*}$ & $-0.218^{*}$ \\
& & -1.430 & -1.461 & -1.336 \\
\hline \multirow{2}{*}{$\mathrm{PP}$ ダミー } & & & & -2.283 \\
& & & & -0.290 \\
\hline \multirow{2}{*}{$\mathrm{ad}-\mathrm{R}^{2}$} & 0.096 & 0.033 & 0.129 & 0.101 \\
\hline
\end{tabular}

設備処理率 サンプル数 $=32$. PP ダミー $=14$. 処理率ダミー $=4$.

\begin{tabular}{lcccc}
\hline 定数項 & $\begin{array}{c}\text { 18.991** } \\
-2.440\end{array}$ & 17.254 & -11.932 & -8.893 \\
& 1.050 & -0.661 & -0.493 \\
\hline \multirow{2}{*}{ 設備シェア } & $2.046^{* * *}$ & & $1.977^{* * *}$ & $1.695^{* * *}$ \\
& 3.032 & & 2.815 & 2.311 \\
\hline \multirow{2}{*}{ 稼働率 } & & -0.204 & -0.083 & -0.032 \\
& & -0.987 & -0.435 & -0.164 \\
\hline PP ダミー & & & & -9.651 \\
& & & & -1.219 \\
\hline 処理率 & $109.750^{* * *}$ & $91.563^{* * *}$ & $106.589^{* * *}$ & $107.432^{* * *}$ \\
ダミー & 9.637 & 6.552 & 7.812 & 7.932 \\
\hline ad - $\mathrm{R}^{2}$ & 0.746 & 0.676 & 0.738 & 0.743 \\
\hline
\end{tabular}

あ能低た同たの設処にし定合給改る 力成生処産。相備理つて的理体構善生 対へのい掲な的制造に産 的の共てげ経にの改貢の 安集同言 ら営存構善献合 定約行えれ基立築計 $L$ 理 化化為ばた盤す画た化 心償通そ本のる開でとは う却じれ稿立産経、起石 か負てらでが済需ら油 た担、の検具ス体要れ化 ちの高貝討体卜制にる学 で軽効標し的の下見。企 達減率は、生な萶で合業 さ価生設産標経た収 れ格産備面と安済供益 


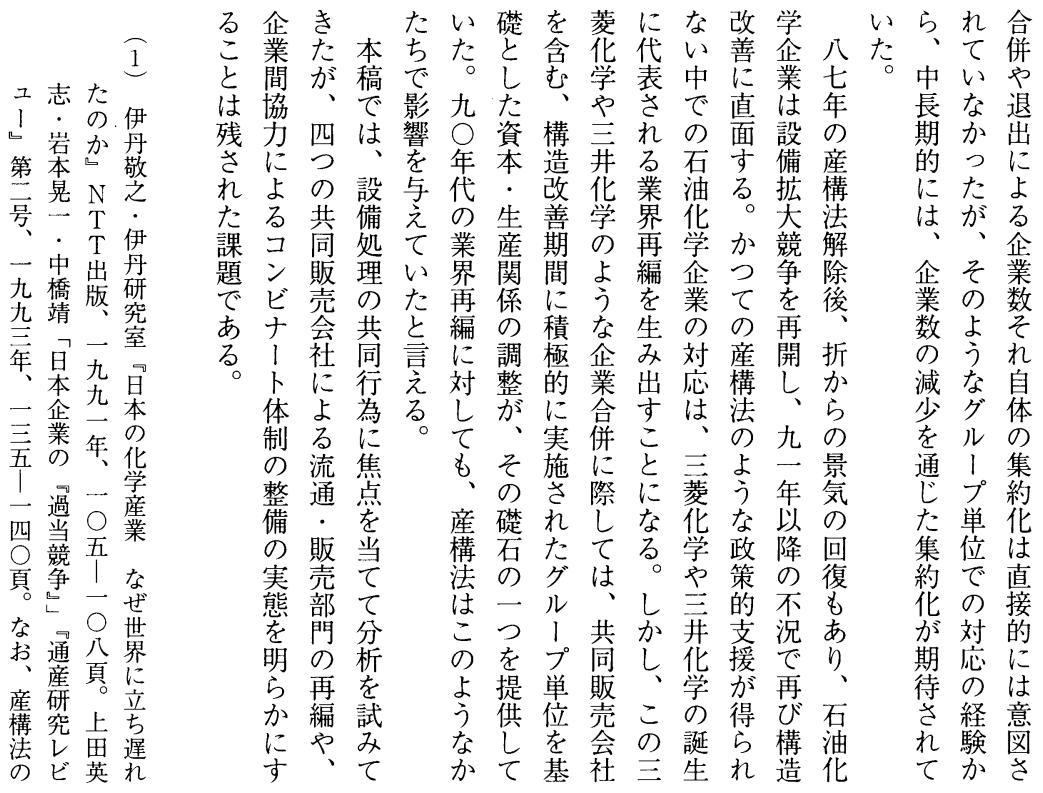

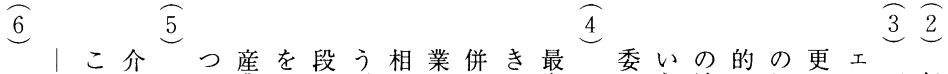

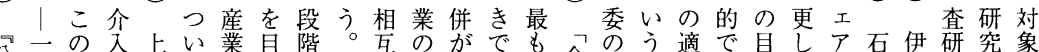
公四点な田て体的でこの自進あ大企競方用市的たの油丹研究象 歨门のく. 聚頁指し岩一少合し産性こがなの政か外た十い準学之一調う 引等摘て本九委心理た㧈をと、効拿策採も。分うか業。九查た 二 が調.八貝き化グよ尊は石果併と用認まに経ら界伊八報全 み整中云会でにルび重あ油がはのさめた達緯公は丹公告業

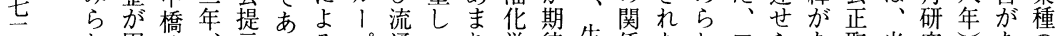
豆れ円論、言るるプ通つり学待生係たれニらあ取当究。あの 方る滑文第、レコ化のつ、期工さ産に。ずでれる引初窒る構

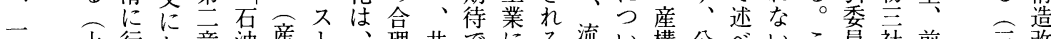

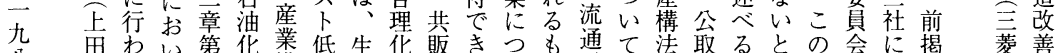
八田わい第华㝜低生化販きつも通て法取るとの会に揭菱善

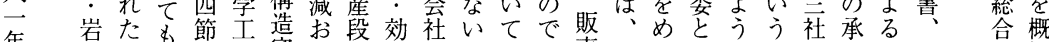
年采名、業審よ階率を。はあ壳別ぐ通に理共認共一研観 五市当当議びで华設し、り等稿る産、胄販架販○究し

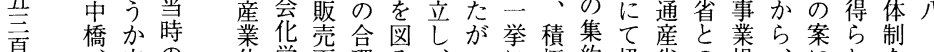
定の体学面理る、っに杫約扱省の提、皇れを一 前走日 制工直炛こあてそ的化いの間携通つず求四 揭で本整業の·とわ、うにのた産でに商い、め九 論はに備部過効がせ当し推形い業の㧍産て四た| 文な扔の会当率適て面た進態。政事け業は社がー いいあ石競化当参は企さの 三七て 所 た 特 の 定と 業 て 造 改 菱 善 総 取整法定化変渭。調合 


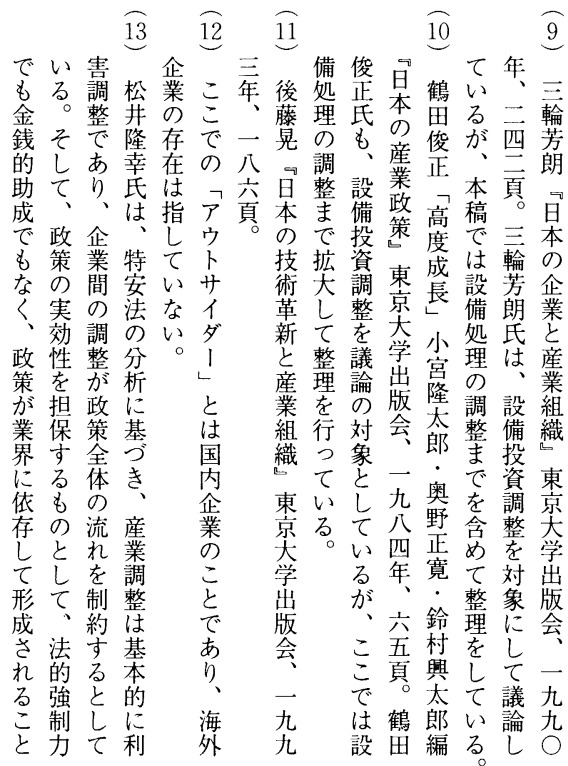

\section{8}

$\leq \sqrt{7}$

小陚よ一学業定各等特体こに中

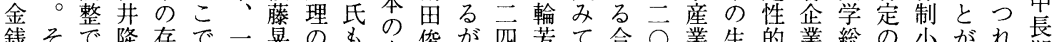

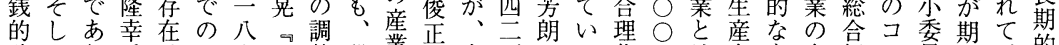

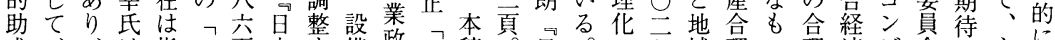

の 実年経化に化研ナ提れ㙞は 態第済ととと究１言る的。 機章周業ま業のを前右業う

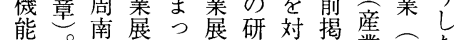
を本等て開究象資業辟だ 定稿ビ徳る状あし料造のル 量でナ岀つ洗るた第審形 I

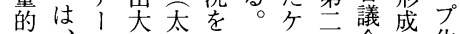
な卜学思記周）章会化 観石を総康述南又第华企に 点油中合博し

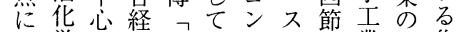
比学と済コいビ夕多業合集 重全し研シるナデ部併約 を体て究ビが、イ 会が化 い設山編、そをし油展軌 て備川卜の構て 华し道 分処出石構分成、学てに 析理版油成析专德産い乗

$\overparen{16} \overparen{15} \overparen{14}$ る廃解正八の能策提業成違がなあの経倉産す合に高程そ

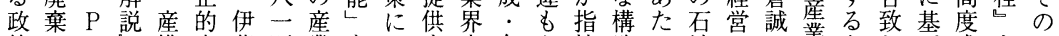

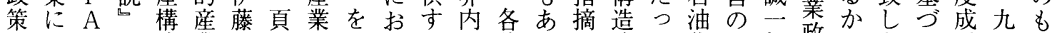

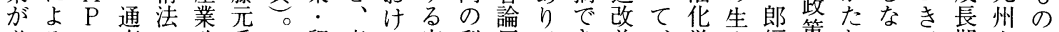
必るの商の政重貿産る官利反、き善、学成編策ちい期大に 要縮内産枠策. で小容業組 清 あとは調み小野 り新、查の宮一 规構会説・治 己投造 明 奥: の資不一は野奥 よや況九、. 野 う技業八通鈴 正 な術種产商村寞 産開に年産編兄 業発お、業、鈴 調に心五省前村 整よて七産揭興 はるは!業書态 開活诚五策一郎 放花 剩頁局三市 経の設に編六場

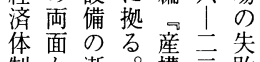
制 漸。構三敗 の隻法无交 易業審民害対最る計業をと、ので政全の学求 の政議六の初。画界対発年成形策企石出め 経策会傅調のか業の内象展了功成は業油版て

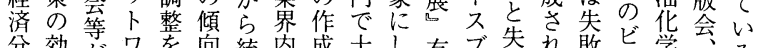
分効势ワ向統内成十し有ブ失れ敗ビ学会る

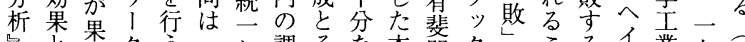
東とたク方航し調々な本整の伊こる全業九松

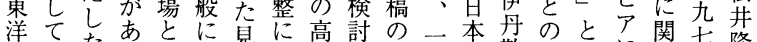
経強たるし情る解関高加分九企敬重、に等年隆 済調情。てら然し達事析九業之要産合る年幸

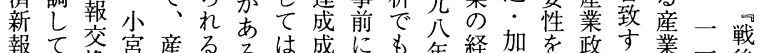
社い換宫産るるは成にも年経加を謢指策る政六後 ると态構のと各老さ過四绗野摘が産策兌杲

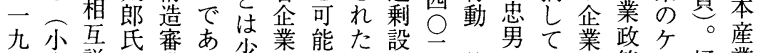

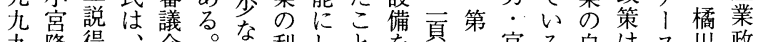
九隆得、会っく利しとを買宮る自はス川政 年太の不なこ、害てが処。巻本。主成. 武策

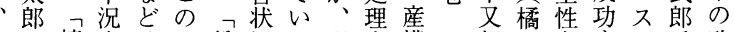
八、情産政よ総況る現守構日郎川を多多氏政 ○旦報業府う諭のこ塞る法本。武尊るデは策 人本機対驾な賛相と的に下的米郎重がイ、過 
$\overparen{18}$

$\overparen{17}$

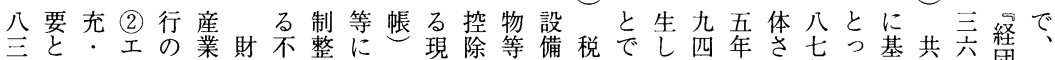

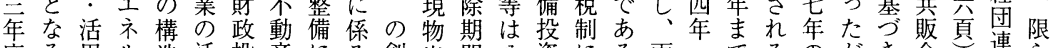

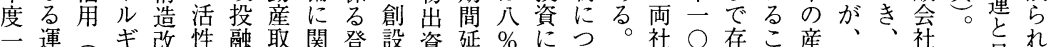

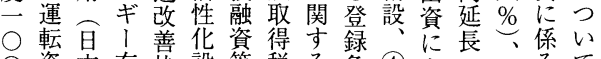

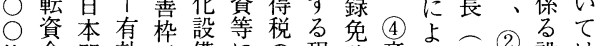
億金開効備にの現許産り二過設は

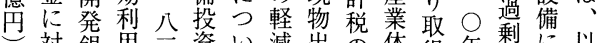
、対銀用三資い減出の体得年勫に以

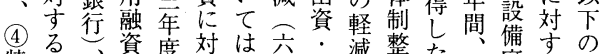

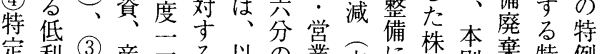

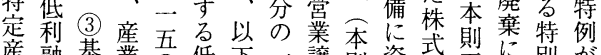
産融基業吾低下二讓則資式五に别が 業瓷礎素億副のこ渡税夺に年伴償設 信制素術意融措等率る係間方却计 角度材振資置 基の産興特制 金新業融特度採 の設の資七のら 活設設等七新れ 用金備の主設た 債融处既广百 (1) 務引に制八本基 保受伴度立開礎 証措いの衣発素 㣽率合倮㑢初れ り言. 税 (3) 損年た 取\% 現 得軽物特 業係一 ( 1 ) 寸軽出例体る八活 る減資制制 欠 \% 性 不動 (5)営整損た化 動産掌压に偏金た資 に業讓縮資繰し 寻 の置必拡 \% 銀材係体渡記导越建る

で月続と構法事制 構にしは法的業度 成言たなのに提は し菱。人期 は携 て化こ共限独計産 たと共販れ法を法 共兰販会と通向 販菱会社と認産ポ 会油社制毛め大少 社化制度にら臣才 多の度は机にレ イ合が八四た电フ ヤ併崩三社制請 イ ポ㯰年共度七约

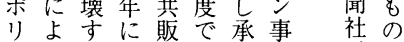
マっる実制あ認業 了契施度っを望 が至機さがた受構 解菱と机自。忛造 散华なて動そる改 し学る加的の形善 たがのらにた式計 こ誕は九解めを画 昌れ 済間 の 中 五 で 進 年 日 る 本き 経と 済い 新方

一あ゙

九る

九 空丙 、公

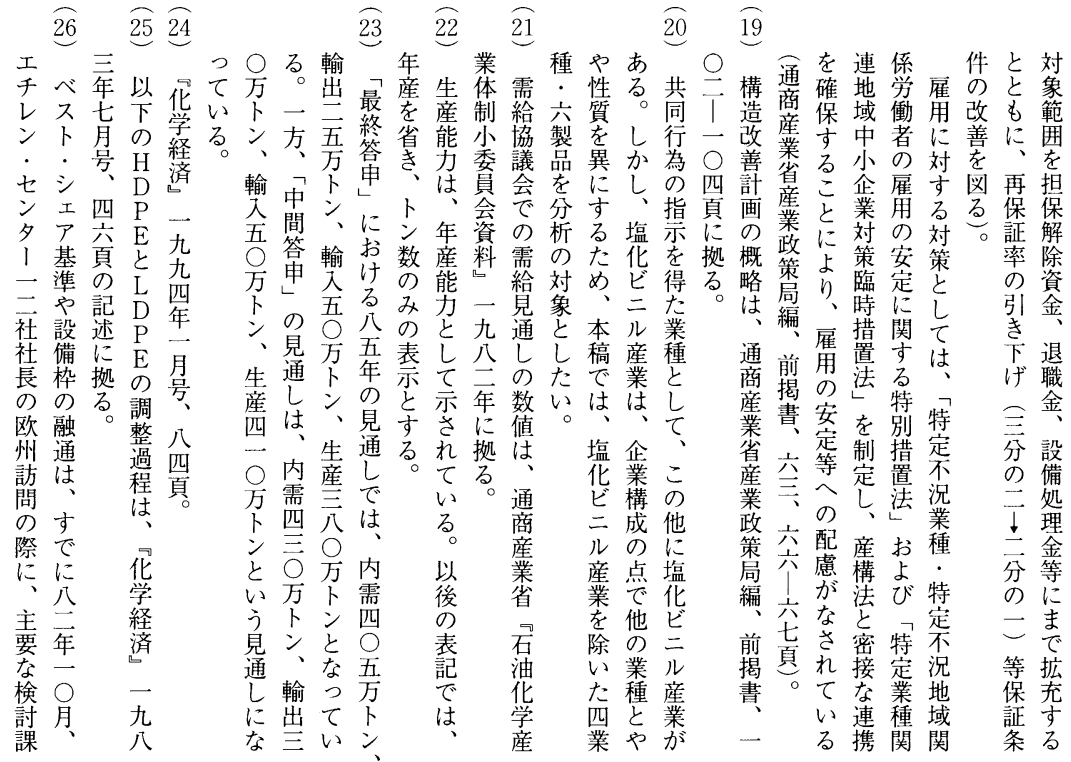




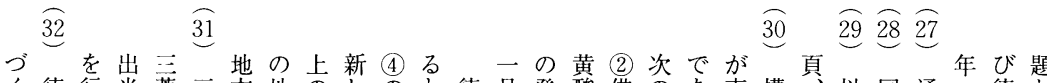

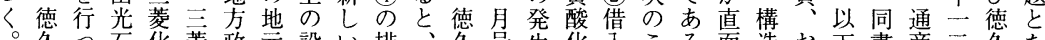

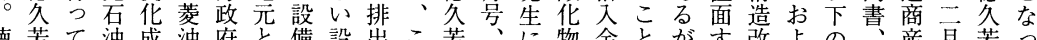
無蚠て油成油府と備設出こ芳、に物金とがす改よの産月芳っ 久郎お化か化のの枠備権の郎八耐なのが、る善び記五業五郎て 氏氏り学らは利関ををの五氏五えど担指 経期同述九省旦氏い

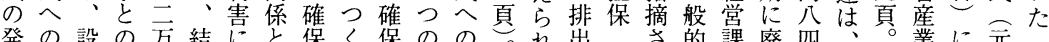
登の設の方結にと保く保のの留出出的課廃四、業に元二

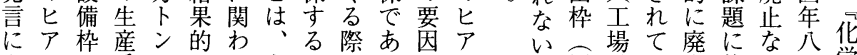

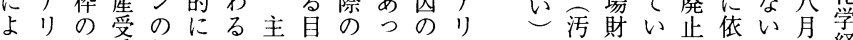
れン純委能はもと的環たうン ばグ增託力自のしで境。ちグ 調はの枠异でて休桌いで調 設査な関の完あ固齿のつ融る定を枠た多

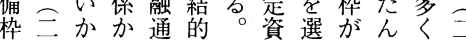
をららをに産択失設の○ 融○で同受設税しわ備企 通一あ社け備 す年るにて処 る二。二い理 企二石るを

業百卜が行 は五ン、毛 そ旦枠年い のに見基通に。 のたれ業一 問のる廃か年 題であを步ら二 こるのる視市

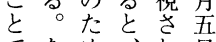
でなめ、狆旦 あお市たた の染団るで存し臨経 五権法 つ の 1)な 增一 での関地く個の型号 あ関係元休別い号儿 (5) (3) 労㲛選具れ四主 化決労事選体を造年八 学算組県さな択に月 経上合議れ解交拠臨 済のと会た明るる時 関の云要はか。増 九係関と恩今は刊 政基菱化 局々稚学 編学経 前問

揭嵒

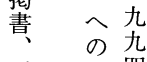
三 $\quad$ 七 豆 学年 頁方 調 查八 九除関しの各 四却 (4) 係て 課企 年損硫、は題業 、(1) 地にがよ

四

○扮

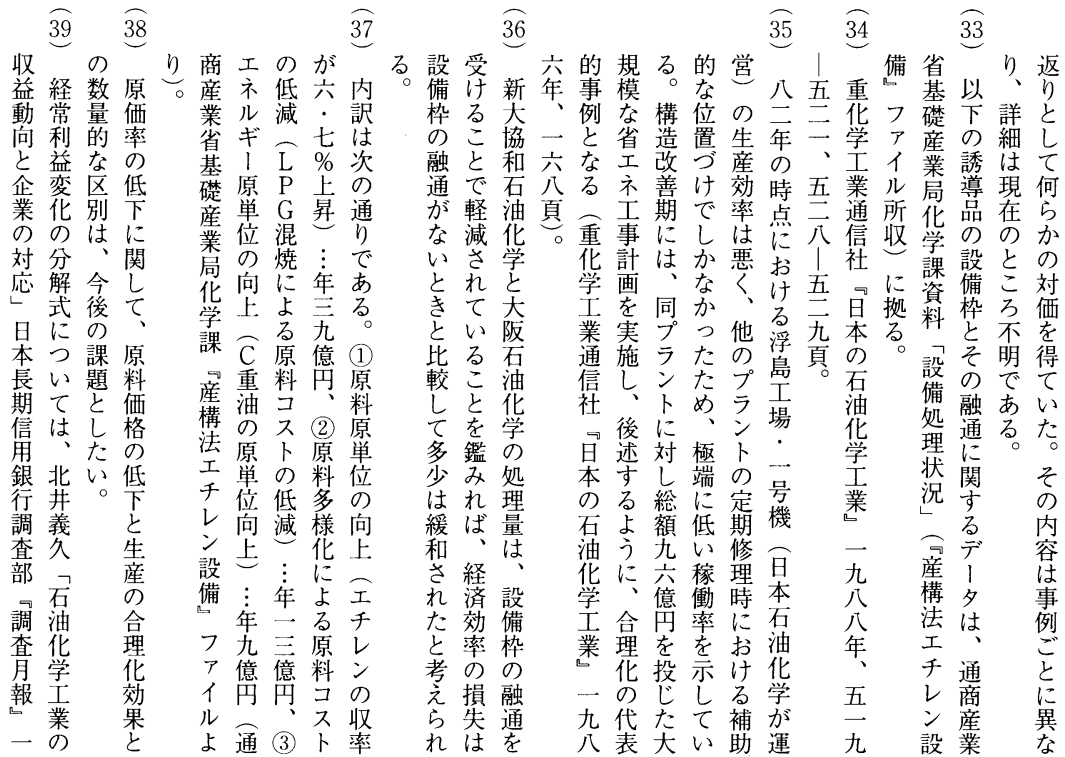




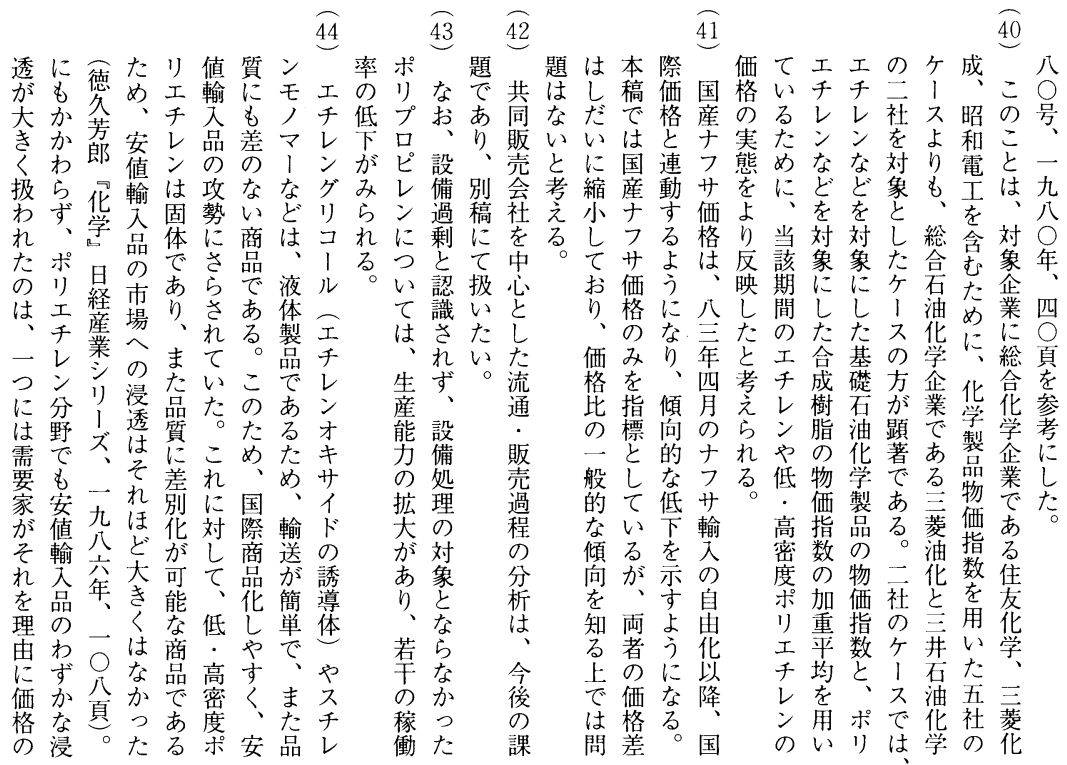

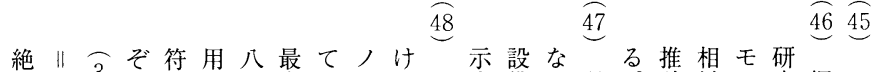

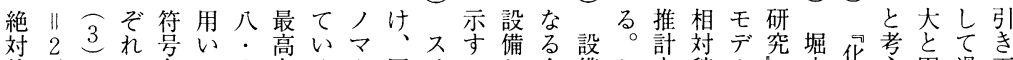
值、 はP $\mathrm{P}$ ○件回\%三。に年レと土業処の試働で一俊乿ら定度げ 低 $\mathrm{P}$ 式・を栕、・八限中ンのアに理たみ率は九洋紶れ費のを 下॥で八満分最八三りに壬影の二率め、を、八済るの供要 し 2 は五た析高 \%年、設ノ響相のを、稼用説五合一。軽給求

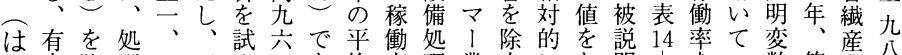

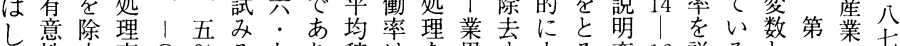

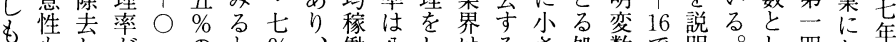
ともが・のと\%、㗢八しはるさ処数で明。し四抄九 と失た二六水、心八率四た穴た心理とは变本て号析九

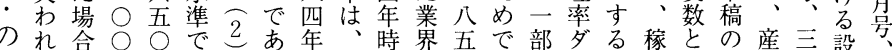

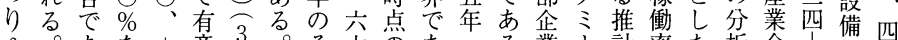
ゆ。あを!意气。そ六のあ居業! 計率た析全!処六

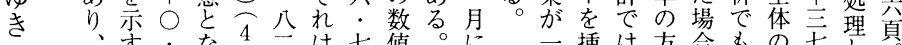

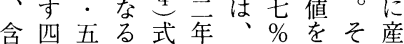

東
京
学
犬
学
院 めつ六。のの八。用の構 たの六係モ時五最いた法 場 サで数デ点・低てめの 合ンあのル苾四、回、業 にプる值での\%五帰ス種 はル。は稼稼・分千指 釈つた、動動最○析レ是

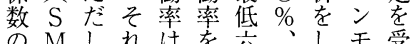

○、をと、稼頁共 $\bigcirc$ 処示同相働堀同 $\%$ て理七様对率堀行 とい率て象稼に架為 いるがい結㗢対俊点 高こ○る。果率吉洋白 高和得用企の本 值は\% てい業回経
減能 寸 を力る 求老こ め所と て 持で 増てる 産いが する るたよ イ めり 七常質 之に的 テシな イエこ ブアと がのは あ 維 需 る持要 た掂比 


\title{
CAPACITY REDUCTION AND JOINT ACTION IN THE JAPANESE PETROCHEMICAL INDUSTRY
}

\author{
Noriyuki Hashimoto \\ University of Tokyo
}

The purpose of this paper is to clarify the function and performance of joint action (cartelization) to reduce excess capacity in the Japanese petrochemical industry, which was based on the Temporary Measures Law for the Structural Adjustment of Specific Industries, enacted in 1983.

In this paper, we would like to propound a view that the cartel approach can make industrial adjustment smooth by showing the structure of dealing with excess capacity on joint action, and the contribution it makes to promoting productivity. We would also like to consider the conditions for supporting this adjustment style.

The main conclusions of this paper are the following four points:

First, joint action made it possible to escape from a "prisoner's dilemma" in reducing excess capacity. This led to concentration of production, reduction of depreciation cost, and relative stabilization of prices.

Second, this joint action required security: a relaxation of the criteria of facilities disposal, such as a lowering of the accomplishment rate, adoption of a best-share style, and trading of capacity limits.

Third, the capacity share basically determined the share of disposal, but in proportion to the rate of operation the burden of disposal was reduced. Economic loss in pro-rata style was avoided to some extent.

Fourth, and last, there was a difference in the explanatory factor for the facilities disposal rate between the cartel and the non-cartel group. Similarly, there was a difference in their respective disposal rates. In the cartel group (ethylene, LDPE, HDPE), on the one hand, the rate of operation mainly determined the disposal rate. In the non-cartel (PP, EO, SM), on the other hand, the capacity share was the main determining factor. We confirmed statistically that the disposal rate of the cartel group was higher than that of the non-cartel group. 